\title{
TELEKI JÓZSEF
}

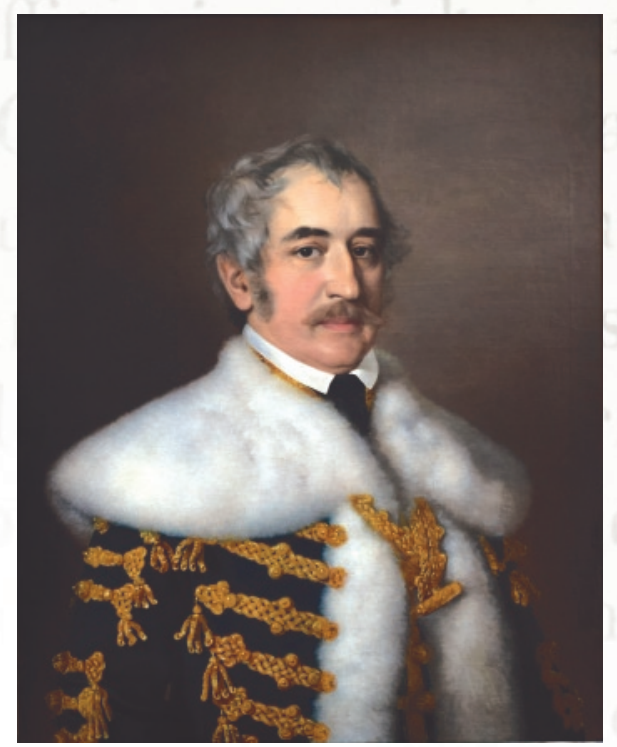

TANULMÁNYOK

AZ AKADÉMIAI KÖNYVTÁR

ALAPÍTÓJÁRÓL ÉS A

MAGYAR TUDOMÁNYOS AKADÉMIA

ELSŐ ELNÖKÉRÖL

movendi Bonipublici studio

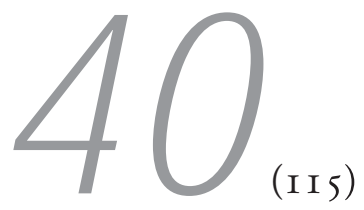

ÚJ SOROZAT 


\section{TELEKI JÓZSEF}

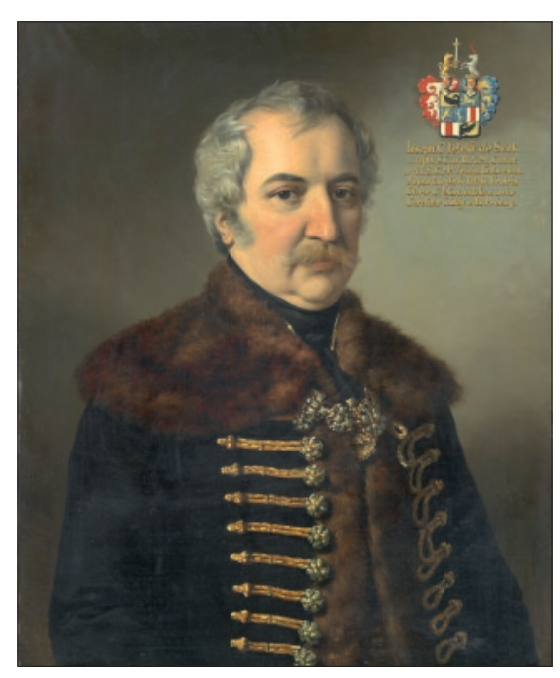

TANULMÁNYOK

AZ AKADÉMIAI KÖNYVTÁR

ALAPÍTÓJÁRÓL ÉS A

MAGYAR TUDOMÁNYOS AKADÉMIA

ELSŐ ELNÖKÉRŐL

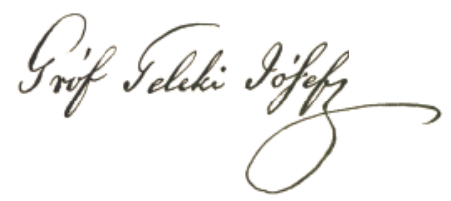


A MAGYAR TUDOMÁNYOS AKADÉMIA KÖNYVTÁRÁNAK KÖZLEMÉNYEI

PUBLICATIONES

BIBLIOTHECAE ACADEMIAE SCIENTIARUM HUNGARICAE

$40(115)$

ÚJ SOROZAT

SOROZATSZERKESZTŐ:

GAÁLNÉ KALYDY DÓRA

\section{TELEKI JÓZSEF}

TANULMÁNYOK AZ AKADÉMIAI KÖNYVTÁR ALAPÍTÓJÁRÓL ÉS A MAGYAR TUDOMÁNYOS AKADÉMIA ELSŐ ELNÖKÉRÖL

SZERKESZTETTE:

MOLNÁR ANDREA

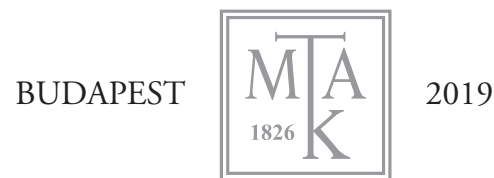


Készült a Magyar Tudományos Akadémia,

valamint a 2019. évi Magyar Tudomány Ünnepe Programtanácsának támogatásával

ISBN 978-963-7451-47-8

ISBN 978-963-7451-48-5 (pdf)

ISSN 0133-8862

DOI 10.36820/MTAKIK.KOZL 2019.TELEKI

Felelős kiadó:

Monok István, az MTA Könyvtár és Információs Központ fơigazgatója

Tipográfia és tördelés:

FoKa art

Nyomdai munkálatok:

Alföldi Nyomda Zrt., 4027 Debrecen, Böszörményi út 6.

Felelős vezető:

György Géza vezérigazgató

A borítón Barabás Miklós: Teleki József portréja (1836),

a kép az Magyar Tudományos Akadémia Művészeti Gyűjteményének tulajdona

A belső címlapon Barabás Miklós: Teleki József portréja (1842),

a kép a Szlovák Nemzeti Múzeum Bajmóci Vármúzeum tulajdona

\section{TARTALOM}

BEVEZETŐ

KOLLÁR ZSUZSANNA

Tekintélyépítési stratégiák a Teleki családban

SZABÓ ÁDÁM

A Teleki család és a könyvek

SZABÓ ÁDÁM

Teleki-gyüjtemény az Akadémián.

Az Akadémiai Könyvtár alapító állományának

története és rekonstrukciója

SALLAI ÁGNES - SZABÓ ÁDÁM

Vegytan az Akadémiai Könyvtár alapító állományában

MÁZI BÉLA

„....egy kis revolutio az Academiában is...”

A Magyar Tudományos Akadémia heti üléseinek

jegyzőkönyvei 1848. március 20. és 1849 . július 2. közöt

HURSÁN SZABOLCS

Batthyány-könyvtárak az Akadémiai Könyvtárban

FÜGGELÉK

A gróf Teleki család könyvgyűjtő és könyvtáralapító

tagjainak családfája

NÉVMUTATÓ 
ta az Akadémiai Könyvtár beköltözött az Akadémia jelenlegi Székházába, a Teleki család hozzájárulásával már nem különgyüjtemény, hanem integráns részét képezi a teljes könyvtárnak.

A magyar művelődéstörténetünk szempontjából kiemelkedő szerepet játszó Teleki családdal és a Magyar Tudományos Akadémia kezdeti évtizedeinek történetével foglalkozó kutatások előrehaladása nemcsak arra adott alkalmat, hogy 2019ben a Magyar Tudomány Ünnepe rendezvénysorozat keretében kiállítással emlékezzünk meg a könyvtáralapító Teleki Józsefről és könyvadományáról, hanem arra is, hogy a munkafolyamat során keletkezett új eredményeket tanulmányokban összegezzük. E kötetben olvashatunk a Teleki család társadalmi beágyazódásáról, a Telekiek könyvgyűjtő hagyományairól, az alapító könyvtár feltárásának folyamatáról és a vegytannal foglalkozó műveiről. Szintén helyet kapott a kötetben az Akadémia 1848-49-es forradalom és szabadságharc alatti tevékenységét dokumentáló forrásközlés, valamint az Akadémiai Könyvtár másik jelentős, a Telekiek könyvtárával összemérhető korai állományrészének, a Batthyányiak könyvtáradományának vizsgálata során elért eddigi eredmények összegzése. A tanulmányok jelentősen bővítik eddigi ismereteinket, új megközelítésből tárgyalják a 19. század elején létrejövő jelentős nemzeti intézményeink létrejöttét, és számos olyan kérdést vetnek fel, amelyek újabb kutatásokra ösztönöznek.

2019. december

Molnár Andrea

\section{KOLLÁR ZSUZSANNA}

Tekintélyépítési stratégiák a Teleki családban

\section{Kísérlet az Akadémia alapításának társadalomtörténet megközelítésére}

A Magyar Tudós Társaság a megalakulását követő évtizedekben kiváló lehetőséget biztosított arra, hogy különböző jogállású, vagyoni helyzetű és társadalmi státuszú szereplők az éppen kialakulóban lévő pesti-budai nyilvánosság előtt egymással közvetlen kapcsolatba lépve együtt érvényesülhessenek. A jelenséget Kerényi Ferenc kulturális érdekegyesítésnek nevezte, és kutatásainak egyik alaphipotézise volt, hogy ezt a politikai érdekegyesítés előzményeként értelmezte. ${ }^{1}$ Az Akadémia intézményesülési folyamatát társadalomtörténeti elemzés keretében elgondolva, ${ }^{2}$ valamint néhány eddig publikálatlan primer forrást és kurrens kutatást is figyelembe véve úgy tủnik, hogy a Tudós Társaság megszervezése nem egyszerűen a különböző politikai vagy vallási felekezethez tartozó csoportok kooperációjának sikertörténete, hanem legalább ennyire elbeszélhető az átrendeződő társadalmi viszonyok által indukált versengés kulturális és tudománypolitikai színtereként is.

DOI-azonosító: 10.36820/MTAKIK.KOZL.2019.TELEKI.1

1 Kerényi Ferenc, Pest vármegye irodalmi élete, Budapest, Pest Megye Monográfia Közalapítvány, 2002, 7-9.

2 A társadalomtörténet kifejezést gyűjtőfogalomként használom arra az átfogó szemléleti keretre értve, amely a kutatásának tárgyát a társadalomtudományok módszertanaival vizsgálja, és megengedi különbözö megközelítések (gazdaság-, mikro-, vagy a kultúrtörrténet) együttes és megengedi kúlönbözo megközelítesek (gazdasäg-, mikro-, vagy a kultúrtörtenet) együttes
alkalmazását. Mindezek segítséget nyújtanak az önmagukban nehezen értelmezhetö primer alkalmazását. Mindezek segítséget nyújtanak az önmagukban nehezen értelmezhető primer források kontextualizálásában, és összetett viszonyrendszerben ábrázolják a múlt eseményeit. Lásd BóDy Zsombor, Ö. Kovács József, Bevezetés a társadalomtörténetbe, Budapest, Osiris, letéröl: KeCSKEMÉTI Gábor, $A z$ MTA BTK Irodalomtudományi Intézetében elkészitendö magyar irodalomtörténeti szintézis megalapozása, ItK, 2014/6, 747-783; HiтEs Sándor, Magyar irodalom a 19. században, Az uij magyar irodalomtörténeti kézikönyv 19. századi köteteinek szinopszisa, ItK, 2015/5, 651-692. Társadalom- és mikrotörténet keveredése biográfában SZILÁGYI Márton, $A$ költö mint társadalmi jelenség, Budapest, Ráció, 2014. Politikatörténeti forrásokon alapuló társadalom- és kultúrtörténeti vizsgálatot hajtott végre Szijártó M. István 2017-es akadémiai doktori dolgozatában: SzIJÁRTó M. István, Emberek és struktúrák 18. századi Magyarorszáoon. A politikai elit társadalom-és kultúrtörténeti megközelitésben 18. szdzadi Magyarorszagon. A politikai elit tarsadalom- es kulturtörténeti megkozelitesben, Akadémiai Doktori Ertekezés, 2017 (webhely: http://real-d.mtak.hu/1036/). Textológia, költészet-, es társadalomtörténet keveredéséboll létrejovố irodalomtörténet-irás: VADERNA évtizedeiben, Budapest, Universitas, 2017. 
Ebből a szempontból nézve az Akadémia rendi viszonyok között létrejövő, de polgári vonásokat is magába foglaló társas intézménynek tekinthető, amely tükrözte a 19. század első harmadának formálódó társadalmi-hatalmi versengését. Mindez látszik abból, hogy a megszervezésében is több, különböző jövedelmi viszonyokkal rendelkező érdekcsoport vett részt, s mindegyik más-más módon szállt síkra az intézmény felállításáért: a vármegyei hivatalviselésben aktív szerepet játszó bene possessionati (birtokosok), az országos politikában érdekelt főrendű mágnás családok és az új értelmiségi életformákban érvényesülő, fóként Pest vármegyei irodalmi klientúra. ${ }^{3}$ E három csoport azonban nem válik el olyan élesen egymástól. Az intézmény megalapításában generációkon keresztül fontos szerepet játszó Teleki családot valahol a három halmaz metszetében helyezhetnénk el: a förangúakhoz tartoztak, vagyoni helyzetük és földtulajdonuk alapján nagy középbirtokosok voltak, mindeközben pedig értelmiségi magatartásformákat adaptáltak. Hogy csak néhány kulturális gyakorlatot említsek: jellemző volt rájuk a nyugat-európai egyetemjárás, tudományos és irodalmi munkák írása és publikálása, könyvgyűjtés, a valláspolitikában, illetve az intézményesülő tudományos-irodalmi életben szervezőként és íróként való részvétel, tudósokkal kialakított baráti kapcsolatok, könyvkiadás és nem utolsósorban fiatal értelmiségiek képzésének finanszírozása.

Az újonnan megalapított Magyar Tudós Társaság bizonyos tekintetben a személyhez kötött mecenatúra nemzeti szintre történő kiterjesztése, pontosabban a 18. századi foúri mecénási tevékenység intézményesített formája volt, jellegét és tevékenységi körét olyan hagyományok határozták meg, amelyekben a Telekiek nemzedékei is felnőttek. Éppen ezért a család történetének egy ilyen típusú újraértelmezése segíthet más megvilágításba helyezni az intézmény alapítását és müködését. A Telekiek azért is kiváló alanyai e vizsgálatnak, mert rendelkeztek olyan kapcsolati hálóval, amelynek a magas rangú udvari személyek mellett részét

3 Az irodalmi klientúra kifejezést e csoportra Kerényi Ferenc használta. Lásd KerénYI 2002, i. m., 157. Az akadémiai alapszabályt és mủködési szabályzatot kidolgozó bizottság, valamint a rendes tagok a harmadik csoportból kerültek ki, az igazgatótanácsi tagok és az adományozók a másik kettőbőll. Az 1830-ra felálló Tudományos Társaság igazgatótanácsában 1848-ig kilenc, 1867-ig pedig tizenöt förangú, tízezer holdnál nagyobb birtokkal rendelkezö ariszkilenc, 1867-ig pedig tizenöt förangú, tízezer holdnál nagyobb birtokkal rendelkező arisztokrata kapott helyet. Közülük hét tag a megalapítástól fogva tagja az igazgatótanácsnak, és ők egyben adományozók is voltak. Az Akadémia 250000 pengő forintos kezdötőkéjéből közel kétszázezret a fớrangú nagybirtokosok adtak össze, a többit a nagy középbirtokkal rendelkezö fö- és köznemesek, de a későbbi években vármegyék és hivatalnokok is adakoztak. Lásd A Magyar Tudós Társaság Évkönyvei I-V. szerk. DöBRENTEI Gábor, 1830-1840, Pesten, Trattner Károly nyomtatása, 1833, 1835, 1837, 1840, 1842, 226-227. vagy A Magyar Tudományos Akadémia munkálódásaiból s pénztára mibenlétéról jelentése az Igazgató Tanácsnak, 1847-58, Pesten, Emich Gusztáv nyomtatása, 1858, 41-48. képezték az éppen kialakuló értelmiségi körök is. Ezeknek az erőforrásoknak az összehangolása, a különböző csoportok összekapcsolása volt a családnak az Akadémia megszervezésében tett egyik legjelentősebb cselekedete. $S$ hogy mi késztette a Telekieket a céltudatos szerepvállalásra? Az a felismerés, hogy a tudományszervezéssel és a literatúrát támogató mecenatúrával járó elismerés pozitívan hatot politikai-hivatali karrierjükre is. Ha tehát meg akarjuk érteni az Akadémia működésének logikáját, érdemes visszatekintenünk az azt létrehozó társadalmi rétegek kulturális tevékenységére és motivációira.

Mivel az intézményalapításban a Telekiek több nemzedékének egymásra épülő munkája érzékelhető rétegként van jelen, tanulmányomban a család történetét kifejezetten az akadémiatörténet kontextusában értelmezem. A vizsgálat két kérdés köré szerveződik. Az egyik, hogy milyen szellemi környezet, milyen hagyományok ambicionálták a Telekiek generációit, elsősorban Teleki (III.) Lászlót (17641821) és ifjabb Teleki (IV.) Józsefet (1790-1855) az Akadémia megszervezésére. ${ }^{4}$ A másik kérdés, hogy milyen stratégiák mentén alkalmazkodtak a családtagok az átalakuló társadalmi környezethez a 18. század végétől a 19. század közepéig. A jelenség megközelítéséhez figyelembe kell venni a Teleki család birtok-, hivatalés tekintélyszerzési stratégiáit is, az egyes családtagok mindennapi életben mutatott viselkedését, házasodási és nevelési szokásait, kulturális tevékenységét. Tanulmányomban megtöröm a hat generáció értékelésének kronológiáját, s közbevetések formájában összefüggésbe állítom az eseményeket Teleki (IV.) József tevékenységével. Ugyanis még megválaszolatlan az a kérdés, hogy miért éppen ő lett a Magyar Tudományos Akadémia első elnöke, mennyiben volt a nádor pártfogoltja, és mennyiben tekinthető kinevezése a tudományos közösség akkori konszenzuális döntésének. Ez tehát e tanulmány implicit kérdésfeltevése. Kutatásaim jelenlegi stádiumában erre még nem adható egyértelmű, forrásokkal alátámasztható válasz, e dolgozatban is csupán arra vállalkozhattam, hogy némileg megvilágítsam Telek (IV.) József társadalmi helyét, a család múltját.

Az Akadémia alapítása nem csupán a mindennapoktól elkülönülő kulturális eseményként gondolható el. A tudományos-irodalmi életben való 18-19. század nemesi szerepvállalás a korábbi századok hatalomszerzési formáinak reformkori

4 A családtagok azonos utóneveit elkülönítendő a levéltári számozás alapján hivatkozom az egyes felmenőkre. Az alábbi generációkról és személyekről esik szó a dolgozatban: Teleki (II.) Mihály (1634-1690), Teleki (I.) Sándor (1679-1754), Teleki (II.) László (1710-1778), Teleki (II.) József (1738-1796), Teleki (III.) László (1764-1821), Teleki (IV.) József (17901855). Lásd: BAKács István, A Teleki család iratai, Budapest, MOL, 1970. 
módozataként is felfogható. Vaderna Gábor némileg hasonló módon összegezte a jelenséget Élet és irodalom címü monográfiájának végén: „...kijelenthető, hogy a 19. század első évtizedeiben a kulturális cselekvés olyan társadalompolitikai mozgásteret jelentett, ahol főuraink egy csoportja (Dessewffy mellett gróf Ráday [II.] Gedeonra, gróf Teleki [IV.] Józsefre vagy gróf Széchenyi Istvánra hivatkozom újfent) kísérletet tehetett arra, hogy a mecenatúrára és a rendi hagyományokra épülő művelődésszerkezetet saját elképzeléseiknek megfelelően modernizálják." ${ }^{5}$ Számolni kell azonban azzal, hogy a karrierkísérletek és érvényesülési törekvések különböznek a tízezer hold feletti birtokkal rendelkező mágnások és a förangú középbirtokosok esetében. Ez a különbözőség pedig elsősorban az életvitelből, illetve az anyagi helyzetből fakadt. A bürokratikus szerveződési mintáknak a tudományok területén történő integratív alkalmazása és a kulturális aktivitás leginkább a protestáns nemesség 18. században felemelkedő csoportjára jellemző, ${ }^{6}$ ez a réteg ugyanis sokáig háttérbe szorult a felekezeti diszkrimináció miatt, $s$ emiatt legitimációs pótlékként tekintett a hivatal, az egyház, valamint a tudomány intézményében való pozíciószerzésre. A protestánsok a magyar nyelv és színjátszás ügye mellett is kiálltak, a legjelentősebb drámafordítások és iskoladrámák is e felekezet tagjaihoz köthetők. ${ }^{7}$ Ezek a hitbéli különbözőségből fakadó sajátosságok erősen meghatározták a protestánsok állásfoglalását nyelvi és tudományos kérdésekben. A következő részben tehát a Teleki család 18-19. századi ${ }^{8}$ hatalomszerzési és vagyonosodási stratégiáit veszem sorra. ${ }^{9}$

5 VADERNA Gábor, Élet és irodalom. Az irodalom társadalmi használata gróf Dessewffy József életmüvében, Budapest, Ráció (Ligatura), 2013, 350.

6 KeRÉNYI 2002, i. m., 18-27.

7 Bíró Ferenc, A felvilagosodás korának magyar irodalma, Budapest, Balassi, 1994, 222; DEMETER Júlia, Az iskolai szinjáték elvilágiasodása (A magyar nyelvü piarista és protestáns ko-

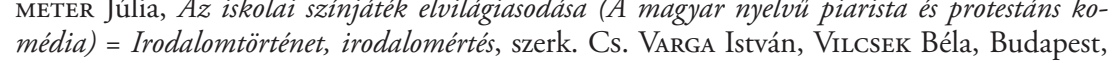
média) $=$ Irodalomtörténet, irodalomértés, szerk. Cs.
Eötvös Loránd Tudományegyetem, 1995, 53-97.

8 A família 15-17. századi előtörténetének rövid, ám pontos összefoglalását lásd: Kocsis Piroska, A Teleki-család irathagyatékának kalandos uitja országos levéltárba kerüléséig. Forrás és érték, Levéltári Szemle, 2017/2, (67), 17-43. Korábban részletes áttekintést adott Kövári László erdélyi családokról írott 19. századi kötete: KőváRI László, Erdély nevezetesebb családai, Kolozsvárt, 1854, 232.

9 Ez a fajta vizsgálati módszer Levi monográfíjáaból Tóth Árpád kutatásain keresztül került a társadalomtörténet-írás homlokterébe, s elsősorban a polgári családok stratégiái kapcsán használták. Giovanni Levi, Egy falusi ördögüzö és a hatalom, ford. PRibojszki Dóra, SzeKeRes András, FenYves Katalin, Budapest, Osiris, 2001, idézi Tóth Árpád, Polgári stratégiák, Pozsony, Kalligram, 2009, 11.

\section{A Telekiek státusza}

„A tudomány, a nemzeti nyelv iránti buzgalom és vallásosság, a Telekiek hármas ösi erénye, mindenikben fényesen igazolja magát, egyiket a másikban, mindeniket Józsefünkben öröklé a haza."

Tompa Mihály ${ }^{10}$

Tompa Mihály személyesen nem tudta tiszteletét tenni Teleki (IV.) József akadémiai elnök temetésén 1855 márciusában, azonban nyomtatásban megjelent búcsúztatójában egyetlen, fentebb idézett mondatban jól összefoglalja a Teleki nemzedékek törekvéseit. Tompa gondolatai nem csupán a beszéd műfaji tradíciójának elemeiként értelmezhetők, hanem a kortársak Telekiekről kialakított véleményét is magában foglalja. Az idézet tanúsága szerint az a családimázs és életforma, amely a Teleki grófokat jellemezte, nem csupán országos intézmények fejlődését segítette elö, de a környezetük elismerését is kivívta. Honnan, milyen pozícióból indult el az a família, amely erre a Tompa által felsorolt három területre koncentrálva a mai napig érezhető hatást gyakorolt?

A Teleki család a 18. században a közé a negyven erdélyi származású főrangú család közé tartozott, akik birtokaik méretét, jövedelmeiket és befolyásukat tekintve az erdélyi politikai elit szemében régi, rangos nemzetségnek és nagybirtokosnak számítottak. ${ }^{11}$ Főrendházi tagságukat még a szatmári békekötés elött alapozta meg I. Lipót 1685-ben a grófi cím adományozásával, tehát korábban, mint az a mintegy nyolcvan magyarországi köznemes család, amely 1711 és 1790 között szerzett grófi vagy bárói címet hatalmas földbirtokkal együtt rangosabb hivatalaiknál és az uralkodóhoz való hűségüknél fogva. ${ }^{12}$ A magyarországi „10 000

10 Tомра Mihály, Halotti beszéd Gróf Teleki József temetése alkalmával, Miskolc, Borsod Vármegye, $1855,11$.

11 „Erdély politikai életében a 18. században nem a főhivatalnok vagy katona arisztokraták a hangadók, hanem a fejedelmi kor végének leghatalmasabb családjai: a Bánffyak, Bethlenek, Kornisok, Hallerek, Telekiek, Wesselényiek. Kivételektől eltekintve, közülük kerülnek ki a gubernátorok, kancellárok, egyéb országos fótisztségek betöltői. (...) Ez a fốnemesség, amelynek legszerényebb birtokú családjainak jószágai néha még 1000 holdat is alig tesznek ki, s csak a leggazdagabbak vagyoni szintje éri el a magyarországi arisztokrata nívót, vagyonban és politikai befolyásban mégis magasan fölötte áll annak a középbirtokos "megyei gyonban és politikai befolyásban mégis magasan fölötte áll annak a középbirtokos "megyei
nemesség«-nek, amelynek legfeljebb saját törvényhatóságában van szerepe, az országgyülénemesség«-nek, amelynek legfeljebb saját törvényhatóságában van szerepe, az országgyủlé-
seken már szinte semmi (fejedelmi kori gyakorlat folytatásaképpen)." Erdély története három seken már szinte semmi (fejedelmi kori gyakorlat folytatásaképpen)." Erdély története három
kötetben II., Az agrártársadalom, föszerk. KöPECzI Béla, Budapest, Akadémiai, 1981, 975.

12 Kaposi Zoltán, A magyarországi nagybirtokrendszer változásai (1700-1945) = Somogy megye múltjából, szerk. RéCSEI Balázs, Kaposvár, (Levéltári évkönyv, 32.) 2001, 97-98. 
holdnál nagyobb úrbéres birtokkal rendelkezö” mágnásokhoz és köznemesekhez képest elmaradt a Telekiek birtokainak mérete. ${ }^{13}$ Fónagy Zoltán Adattárának bevezető tanulmányában „a bene possessionatus nemességgel egy vagyoni nívón álló, úgynevezett nagy középbirtokosok között” említi a fónemességhez tartozó Teleki grófokat. ${ }^{14}$ Szintén erre a rétegre volt jellemző, hogy uradalmak helyett sok kisebb birtokkal, házzal, jószággal rendelkeztek elszórva az ország területén, amelyek nem gazdagon termő, hanem inkább állattartásra alkalmas területeken helyezkedtek el. Noha e birtokok nem képeztek egységes uradalmat, előnyük volt, hogy mobilissá tették tulajdonosaikat: Erdélyből akár Bécsig vagy Pozsonyig is eljuthattak úgy, hogy átutazóban minden egyes éjszakát saját birtokaikon tudtak tölteni. Az a társadalmi réteg, amelyhez a Telekiek is tartoztak, életvitelét tekintve a liberálisabb középbirtokos nemességhez és nem a birodalmi arisztokráciához állt közelebb. Noha a Telekiek a második legnagyobb földbirtokkal rendelkező nemzetség voltak az egyébként uradalmakkal nem rendelkező Erdélyben a Bánffy család után, éves jövedelmük is elmaradt a magyarországi mágnásokéhoz képest. (F. Csanak Dóra monográfiájában említi, hogy a koronaőr Teleki József jövedelme évi 10000 forint volt, frának, Lászlónak, Józsefhez képest megnövekedett jövedelmeire pedig a válási szerződés-tervezetéből tudunk következtetni, ahol csak a Teleki Máriának ígért rész meghaladta az apa éves jövedelmét. ${ }^{15} \mathrm{~A}$ családtagok Erdélyben kulcshivatalokat töltöttek be, a református egyházmegyék világi főkurátorai voltak, templomok és kollégiumok építésében vettek részt, az erdélyi udvari kancelláriánál és a főkormányszéknél (guberniumnál) igen jelentős pozíciókat szereztek, de országos és bécsi udvari méltóságokat alig valaki kapott közülük. ${ }^{16}$ A családból elsőként Teleki (IV.) József nyert kitüntetett helyet az országos politikában, és - hasonlóan felmenőihez - a rangja mellett ő is tudományszervezői munkájával vívta ki a komolyabb politikai elismerést. Ez a speciális összefüggés politika és literatúra között a következő példával érzékeltethető: az 1839/40-es

13 FónAgy Zoltán, A nemesi birtokviszonyok az úrbérrendezés korában, Adattár I, Budapest, MTA Bölcsészettudományi Kutatóközpont Történettudományi Intézet (a továbbiakban MTA BTK TTI), 2013, 57.

14 Fónagy 2013, i. m., 62

15 F. CsanaK Dóra, Két korszak határán. Teleki József, a hagyományörzö és a felvilágosult gondolkodó, Budapest, Akadémiai, 1983, 341, illetve Teleki László és Mária válási szerződésének tervezete (1800 elején), MTA KIK Kt, Vegyes 2r 18. sz. III. 9. Összehasonlításképp lásd Esterházy Miklós magánkiadásainak összegét: SzABAD György, A tatai és gesztesi Esterházyuradalom áttérése a robotrendszerröl a tökés gazdálkodásra, Budapest, Akadémiai, 1957, 45.

16 Teleki (IV.) József és Teleki (III.) László tisztségeit lásd: PáLmÁny Béla, A reformkori magyar országgyülések történeti almanachja 1825-1848, II., Budapest, Országgyủlés Hivatala - Argumentum Kiadó, 2011, 172-173; SZÁNTAY Antal, Teleki Sámuel a jozefinizmus szolgálatában, Világosság, 1987/ 8-9, (28), 548-555. pozsonyi országgyűlésen már a Magyar Tudós Társaság elnökeként számolt be az intézmény igazgatásáról a felsőtáblán, ahol - egykori titkosrendőrségi jellemzése szerint - jobbközép besorolású politikusként: „A vallási kérdésig keveset beszélt majd erről és minden más kérdésről nagyon sokat. Alapos tudása van, beszédei szépek és jók, jól beszél rögtönözve. Szívesen hallgatják, és általánosan figyelembe veszik. A vallási kérdésekben a protestánsok vezetője volt és pártját szemlélettel vezette." ${ }^{17}$ Teleki József diétai elfoglaltságai miatt ebben az évben mindössze hét akadémiai kisülést elnökölt végig, tizenhét esetben helyettesíteni kellett (ahogy az alelnök Széchenyit is), ${ }^{18}$ majd országgyülési szereplését követően 1840 májusában másod-koronaőrré nevezték ki. ${ }^{19}$ Politikai pályája együtt emelkedett tudományos törekvéseivel, tudós karrierjével, s amikor szükséges volt ez utóbbit az előbbi javára háttérbe tolta.

A 18. század folyamán jelentős politikai térvesztést elszenvedő főrangú mágnásokkal szemben a Telekiek nemzedékről nemzedékre tehetséget mutattak a Tompa Mihály által is megnevezett három területen, szinte transzgenerációs stratégiaként épültek egymásra döntéseik. Ilyen volt a 18. század elején kezdődő, határokon átnyúló házasodási stratégia, aminek révén fokozatosan átterjeszkedtek Magyarországra: Észak-Erdély felől Nógrád és Pest vármegyén és a Mátra hegységen át Pest környékéig. ${ }^{20} \mathrm{Az}$ átterjeszkedés nem egyedülálló jelenség az erdélyi förangúak között, és esetükben sem jelentette az erdélyi közéleti színtér elhagyását, az erdélyi birtokok vagy tisztségek teljes feladását. Inkább mondhatni, hogy egyfajta kétlakiság jellemezte őket: gyermekeik első pár évükben olyan jó képességű, nagy műveltségű nevelők tanítványai, mint például Bod Péter vagy Cornides Dániel. Alsó- és középfokú iskoláikat a család által pártfogolt kollégiumokban, rendre Kolozsváron, Marosvásárhelyen végzik, jogot Pesten tanulnak, külföldön 2-3 évet töltenek híres egyetemeken, elsősorban Göttingenben, majd szinte azonos

17 PálMÁNy 2011,i.m., 172-173.

18 A Magyar Tudós Társaság Évkönyvei V., Pesten, Trattner, 1842, 37.

19 Teleki József a negyvenes évek elején érte el karrierje csúcsát, amikor egyszerre volt Szabolcs vármegyei főispán, erdélyi kormányzó, koronaőr és a Magyar Tudós Társaság elnöke. PÁlmány 2011, i. m., 172-173.

20 Magyarországi birtokokhoz jutott erdélyi nemesek voltak még a Bethlen, Kemény, Lázár, Tolvay és Toldalagi famíliák. Lásd Pálmány Béla, A magyarországi nemesség társadalmi tagolódása $(1686-1815)=$ Mágnások, birtokosok, címerlevelesek, szerk. ÓDOR Imre, PÁLMÁNY Béla, TAKÁcs Péter, Debrecen, HIK, 1995, 61 
európai körútra indulnak, ${ }^{21} s$ utazásaik során az országok általános viszonyait tanulmányozzák. A körútról Bécsbe visszatérve bemutatják magukat az udvarban, néhány bécsi bálon és esten részt vesznek, ismeretségeket kötnek, majd hazatérve a számukra lehetséges hivatali pálya ranglétráján folytatják a munkát. A házasodásra is ez idő tájt kerül sor, ha sor kerül. A család magyarországi jelenléte Erdély és a Magyar Királyság viszonya szempontjából is érdekes: pesti pozíciószerzéseik mondhatni ráerősítettek erdélyi tekintélyükre és fordítva, ilyenformán fontos diplomáciai szerepet is betöltenek a két térség között. Ezt ismét csak az akadémiai elnök Teleki József főkormányzói szerepvállalásán keresztül lehet megfigyelni: ő enyhítette például az 1848-as forradalom idején Erdélyben a nemzetiségek közötti feszültséget az uniót illető követelések kapcsán. ${ }^{22}$ Teleki József a negyvenes évektől már nemcsak hivatali pályán mozgott, hanem intenzívebben bekapcsolódott a politikába is. Nála 20 évvel fiatalabb féltestvére, az 1861-ben öngyilkosságot elkövető politikus Teleki László, midőn éppen csak bekerült a közéletbe, ${ }^{23} 1841$. decemberi levelében az alábbi módon érvelve kérte bátyját, hogy induljon el az erdélyi kormányzóválasztáson: „Istenre kérlek indits abban valamit - ha lehet hogy ne Jósikát hanem téged nevezzenek ki kormánynoknak - Nem képzeled menynyire ohajtnak itt téged - Anyám tudod nem kivánja kineveztetésedet s erről irni fogok neki a jövő postán - de neked a közjó tekintetéből kivánnod kell, mert bizonyosan sehol sem lehend olly független állásod mint itt, és tehát sehol nem fogsz annyi jót tehetni mint itt. Mutasd meg kérlek ezen levelet anyámnak is s mond [sic!] meg neki, hogy én véleményében teljességgel nem osztozhatom s okait a jövő folytán mind megczáfolandom - most teljességgel nincs időm reá, mert követi tudósitással és conferencziával kell bibelődnöm.” ${ }^{24}$

Ez a levél egyrészt azt sugallja, hogy Teleki József - talán természetéből adódóan - némileg idegenkedett ilyen léptékủ politikai felelősségre szert tenni, másrészt illusztrálja, hogy a családon belül létezett valamiféle szövetség, amely lehetővé tette ezt a fajta beszédmódot, és amelyben a szűk családtagok egymás segítőiként és

21 A külföldi körútra mindannyian Bécsből indulnak, majd „Prágán, Drezdán, Lipcsén, Weimaron, Erfurton át előbb Göttingába” utaznak. Göttingenben egy-két évig tanulnak, majd egy-másfél hónap Anglia következik, aztán Párizs és néhány ahhoz közeli francia város, ÉszakOlaszország, délnémet városok, majd visszamennek Bécsbe. Vö. IváNYi Béla, $A$ széki grófTeleki család Gyömrői levéltára, Szeged, kiadja a gr. Teleki család gyömrői ága, 1931, 25-27.

22 KővÁri László, Erdély története 1848-49-ben, Pest, Emich Gusztáv, 1861.

23 „betöltve 30. életévét, csak 1840 februáriában kapott királyi meghívót az 1839. június 2-a óta ülésező országgyülés felsőtáblájára." HonvátH Zoltán, Teleki László 1810-1861, Budapest, Akadémiai, 1964, 111

24 OSZK Kézirattár Teleki László levele Teleki Józsefnek 1841. december 17. tanácsadóiként léphettek fel. S mivel Teleki nem házasodott meg soha, így számára a család apja második feleségét és testvéreit jelentette. Báró Mészáros Johanna, József apjának özvegye a levélből következtethetően olyan viszonyt ápolt a férje halála után is a nála mindössze hat évvel fiatalabb mostohafiával és édes gyermekével, Lászlóval, hogy előttük bátran kinyilváníthatta véleményét politikai kérdésekben a családon belül, és véleménye számított is, argumentációra legalábbis érdemesnek tartották. Itt fontos azt is megjegyezni, hogy az Akadémia alapításakor a könyvtárat és annak őrzésére 5000 forintot adományozó „Teleki család” lényegében őket hármukat, és Teleki Ádámot, valamint Teleki Sámuel testvérüket jelenti. ${ }^{25}$

A magyarországi átterjeszkedéssel összefüggött egy másik stratégia is: a földbirtokok szerzése, amely sokszor házasodás útján történt. A megfelelő házastársak kiválasztásánál előnyt élveztek a birtokaikhoz közel lévő uradalmak leendő tulajdonosai, és több alkalommal is a csekély férfi örökössel rendelkező famíliákból kerültek ki a menyasszonyok, de legalábbis minden házasság mögött felfedezhető valamilyen stratégiai logika is, amely persze nem jelenti azt, hogy frigyeik ne lennének szabad választás eredményei. A sajátos választásokról és a szülői ráhatásról F. Csanak Dóra is írt Teleki (II.) József, valamint Teleki (III.) László házasságának története kapcsán. ${ }^{26}$ Ugyanilyen módon olvashatunk nála Teleki (II.) József birtokgyarapítási és birtokmodernizálási stratégiáról is. A gyömrői birtok Ráday Eszter hozományaként, a sziráki pedig a Róth-családtól öröklődött a Telekiekre. ${ }^{27}$ A házasságkötésben fontos szempont volt az azonos felekezethez tartozás, $s$ igaz ugyan, hogy Róth Johanna evangélikus volt, ám a türelmi rendelet elött az említett birtokok mégis a református hitélet állandó helyszínei lettek. Az is megfigyelhető, hogy a választott famíliák a mindennapjaikban hasonló kulturális gyakorlatokkal éltek, gondoljunk csak a könyvgyüjtésre, az irodalom vagy a színház iránti érdeklődésükre. ${ }^{28}$ A magyarországi protestáns közösségekbe történő integrálódás és a

25 Döвrentei Gábor, szerk., A Magyar Tudós Társaság Évkönyve, Pesten, Trattner Károly, 1833, 51. 26 F. CSANAK 1983, i. m., 97-101.

27 Benda Kálmán, Soós István, A Teleki család és Teleki László = Teleki és kora (Discussiones Neogradienses 3), szerk. Praznovszky Mihály, Rozsnyó Ágnes, Salgótarján, Nógrád Megyei Múzeumok Igazgatósága, 1987. „Az 1770-es évek elején megvásárolta Beleznay Miklós generális ócsai birtokát, s a következö évben újabb Pest megyei birtokot szeretett volna szerezni - akár csere útján is. Egy esetleges ecsédi birtokcsere is szóba került. Ezekkel, a csak részben megvalósult tervekkel valószínüleg az volt a fó célja hogy a pesti piac lehetöségeit kihasználva növelje jövedelmét." F. CsANAK 1983, i. m., 42.

28 A Ráday család a magyar kultúrában. 300 éve született Ráday Gedeon, szerk. Berecz Ágnes, Budapest, Dunamelléki Református Egyházkerület Ráday Gyüjteménye, 2014; KeRÉNY Ferenc, A szinházzjáró Telekiek. Kis müvelódéstörténeti traktátus a 18. századból = Szinek, terek, emberek. Irodalom és szinház a 18-19. században, Ráció (Ligatura), 2010. 
nemzedékről nemzedékre átöröklött művelődés- és tudományszeretet egyaránt a tudatosan konstruált családimázs alapelemévé vált a Telekieknél, csakúgy mint azoknál a régi protestáns köznemesi famíliáknál, amelyek a 18. század végén vagy 19. század elején érték el grófi vagy bárói rangra való emelésüket, ilyen például a hasonló méretű birtokokkal rendelkező Ráday, Podmaniczky, Beleznay, Prónay família. ${ }^{29}$ A Róth családot is bátran ide sorolhatjuk. Róth Tamás, Teleki (III.) László nagyapja szintén peregrinált, ám a műveltséghez való viszonyát unokájával való levelezésével lehet a legjobban megmutatni. A kis László hat évesen már tudott szlovákul, németül, magyarul, hét évesen pedig már latinul és németül is írt leveleket, s nem egyet már segítség nélkül, egyedül fogalmazott meg. Róth Tamásnak nem volt férfi örököse. Családjában (III.) László volt az első fiúgyermek, talán ezért is alakított ki szoros kapcsolatot unokájával, aki négy esztendős koráig a sziráki birtokon nevelkedett. László első levele is nagyapjához íródott. Következzék néhány részlet levélváltásukból:

„Kedves Nagy Atyám Ur!

Hogy ujjabanis jelét adhassam az irásban való előmenetelemnek és Fiui tiszteletemnek küldöm ezen Levelemet magam személyem helyett az udvarlásra, melyben most egyéb ujságot nem irhatok, hanem hogy én katonává szándékozom lenni, de még kezet nem adtam s nem is adok a Nagy Atyám Ur hire nélkủl noha eleget kinálgatott egy Verbungon lévő Scripsi Fráter valami Penna nevű Muskéttal. (...)”

Ezen levélre való válasz:

\section{„Kedves Latzi Unokátskám!}

(...) Mind a két rendbéli leveleddel meg őrvendeztetem látván szép gyakorlásodat az írásban, tovább is járj el abban, 's tanulásban magadat jövendőbéli hasznára 's előmeneteledre. Inkabb tanulj, hogy sem katonának meny. Ritkan hozott katona valamit élelmire magával haza, sőt amije volt is onnan hazul azt a Papásokkal [értsd: pajtásokkal - K.ZS.] győzte el-kőlteni; de a Penna napról napra szaporittya a konyhát, azért te tsak ahoz tartsd magad, 's tanulj hogy hasznát vehessed. (...)”30

29 Kerényi 2010, i. m., 18-19, Fónagy 2013, i. m., II., Beleznay család: 789-790, Podmaniczky: 1277-78, Prónay: 1293-95, Ráday Gedeon: 1310, Teleki: 1442-44.

30 A tizenegy fólióból álló, negyedrét füzet tizenhárom magyar, német és latin nyelven írt levelet tartalmaz. A levelek zöme Királyfalvi Róth Tamáshoz és feleségéhez szól, de helyet kapnak benne anyjának és az akkor csupán három éves István öccsének írt levelei is. Az első levele 1770. december 4-én Sorostélyon íródott Szirákon élő nagyapjához. László 1764. szeptember 3-án született Szirákon, amikor tehát e levelet írta, mindössze hat éves volt. ANR DJC fond nr. 928 , crt. nr. $412,5 \mathrm{v}$.
A sokatmondó sorokból többféle következtetés is levonható. Egyrészt árulkodóak a katonai pályával szemben támasztott elöítéletek, másrészt kiolvasható belőle, hogy a műveltség megszerzése nem öncélú szórakozás, nem pusztán a foúri művelődéskoncepció része. Ellenkezőleg: a gazdagodás, a hatalomszerzés egyik eszközét látták benne, olyan társadalmi gyakorlat volt, amely a felemelkedéshez vezető utat jelentette számukra. Végigtekintve a Telekiek hat generációján, úgy tűnik, ez a felfogás egyre markánsabban lett jelen a családban az idő előrehaladtával, így tehát a birtokszerzések, a Magyarországra történő áttelepülés, a házasodási stratégiák mellett a műveltség és a tanultság egyre inkább előtérbe került.

\section{Családtörténet az Akadémia kontextusában}

A Teleki család rangját az Erdélyi Fejedelemség Habsburg-integrációját előkészítő ifjabb Teleki (II.) Mihály kővári fókapitány alapozta meg, ő volt Teleki (IV.) József későbbi akadémiai elnök apai ágú szépapja. Ez a Teleki I. Apafi Mihály főtanácsosa, II. Rákóczi György testőrkapitánya, Erdély főgenerálisa, s történeti áttekintések tanulsága szerint ellentmondásos képességekkel bíró politikus volt, akinek Erdély magyar korona alá történő visszakerülésében meghatározó szerepet tulajdonít a történetírás. ${ }^{31}$ Érdemeiért, ahogy arról már szó volt, 1685-ben I. Lipót grófi rangra emelte, és 1690. augusztus 21-én Thököly ellen harcolva a zernyesti csatában hunyt el. Ez a mozzanat, illetve az a tény, hogy a család a törökök ellen vívott háborúkban részt vállalt, összefügghet azzal is, hogy a későbbi leszármazottak, Teleki (III.) László Hunyadiról szóló történelmi drámát írt, fia pedig hétkötetes történeti monográfiát publikált $A$ Hunyadiak kora Magyarországon címmel. ${ }^{32}$ (1. kép) A történetírás Teleki (II.) Mihályt tekinti a család rangját és vagyonát megalapozó első Telekinek: „családjának tetemes jószágokat és kincseket hagyott hátra." ${ }^{33}$ Halála előtt ő is, majd halálát követően felesége, Weér Judit is jelentős

31 TrócsánYi Zsolt, Teleki Mihály, Erdély és a kurucmozgalom 1690-ig, Budapest, Akadémiai, 1980, 16; BENCzÉDI László, Rendiség, abszolutizmus és centralizáció a XVII. század végi Magyarországon (1664-1685), Budapest, Akadémiai, 1980; VARGA J. János, A fogyó félhold ár nyékában, Budapest, Gondolat, 1980; MaKKaI László, SzÁsz Zoltán, Erdély története 1606tól 1830-ig, Budapest, Akadémiai, 1986; Hereper János, Adatok Teleki Mihály és udvara életéhez (Töredék) = Herepei János, Adattár XVII. századi szellemi mozgalmaink történetéhez III., Budapest, Kossuth Nyomda, 1971, 13-31.

32 TеLекI László, Hunyadi Laszlónak meg ölettetése, lelöhely és jelzet: MTA Kézirattár, Rui $4{ }^{\circ}$ 133/I. 90 levél; TeLEKI József, Hunyadiak kora Magyarországon I-V, Pesten, Emich Gusztáv könyvnyomdája, 1850-55.

33 NAGY Iván, Magyarország családai czimerekkel és nemzedékrendi táblákkal, 11. kötet, Budapest, $1868,81$. 
kölcsönöket adott az erdélyi kincstárnak. Amikor a kincstár már a kamatokat sem volt képes fizetni, a család gyermekei (Teleki fiai, Mihály, László, József, Pál és Sándor) kompenzációképpen - más famíliákhoz hasonlóan - hitbizomány útján egy 1697. április 20-án kelt oklevélben megkapta a Római Szent Birodalmi grófi rangot, melyet a család évszázadok múlva is használt. ${ }^{34}$ Később Teleki (II.) László még 3000 forintot is fizetett a mainzi érsek pénztárába a maga és utódai nevében, mert a diploma kiadásakor adminisztratív hibák keletkeztek, így azt újra érvényesíteni kellett. ${ }^{35}$ A Reichsgraf cím tulajdonosa jogot kapott a birodalmi gyủlésen való részvételre is. ${ }^{36} \mathrm{~A}$ Habsburgok által adományozott nemesi cím nehezen értelmezhető a magyar történelem intézményén belül, hiszen Magyarország nem volt a Német-Római Birodalom része. A cím jelentősége elsősorban Erdély Habsburg Monarchiához való kötődésének kifejezésében rejlett, Teleki (II.) Mihály sokat tett azért, hogy Erdély magyar - és ezáltal Habsburg - fennhatóság alá kerüljön, így a címnek szimbolikus jelentősége is van. Másrészt pedig a család nemességét igazoló 1685-ös dokumentum ugyan megsemmisült, de a nemesi címert 1697 ben kiegészítették a birodalmi grófi címmel, így ez utóbbi vált a család - már korábban is meglévő - nemességének egyik legékesebb bizonyítékává. ${ }^{37}$

Teleki (II.) Mihálytól nemcsak a vagyont, a rangot és a ranggal járó Habsburg-pártiságot, hanem a felekezeti kötődést is örökölte a család ezen ága. Ő még nem rendelkezett magyarországi birtokkal, ${ }^{38}$ a család tulajdonában ekkor még az uzdiszentpéteri, sorostélyi, kővárhosszúfalui, árvai, huszti és verhovinai, gernyeszegi telkek voltak, ez utóbbiban Teleki Mihály és később unokája, Teleki

34 BAKáts István, A magyar nagybirtokos családok hitelügyletei a XVII-XVIII. században, Budapest, 1966; R. VÁrKonyI Ägnes, Erdély változásai, 1660-1711, Budapest, 1984. Teleki Lászlónak az édesapjáról írt terjedelmes német nyelvủ nekrológja: Lebensbeschreibung des Reichsgrafen Joseph Teleki von Szék, Szeben, 1800. Megjelent a Siebenbürgische Quartalschrift 1801, 110-146.

35 A Teleki család német-birodalmi grófsága, Századok 1903, 767-774, idézi F. Csanak 1983, i. m., 27.

36 KővárI 1861, i. m., 233-236; IváNYI Béla 1931, i. m., A rangra vonatkozó irodalom: Karl Ottmar von ARETIN, Das Alte Reich 1648-1806. Band 1: Föderalistische oder hierarchische Ordnung (1648-1684), München, 1993. Lásd még: Helmut Neuhaus, Das Reich in der frühen Neuzeit, München, Oldenbourg, 1997.

37 „1697. április 20. Bécs. I. Lipót király Széki Teleki Mihályt, Lászlót, Józsefet, Pált és Sándort és ezek családjait római szent birodalmi grófi rangra emeli. Papiroson, az erdélyi gubernium által 1751. szeptember 26-án Szebenben kiadott hiteles másolatban. I. Levéltár, Elench. XXIV. fasc. VIII. No. 61. Teleki Mihály grófi rangemelését tudató királyi leirat 1696. dePÁlmány 1995, i. m., 75.
(II.) László is szívesen tartózkodott. ${ }^{39}$ Fennmaradt források bizonyítják, hogy Mihály komoly mecénási tevékenységet folytatott, egyes becslések szerint vagyona felét fordította a kolozsvári református kollégium diákjainak taníttatására. ${ }^{40}$ Mihály második fia, I. József megözvegyülése után feleségül vette (Árva) Bethlen Katát, aki az első magyar barokk írónőként és könyvgyűjtőként vált ismertté. Már (I.) József is gyüjtött könyveket, $s$ tudható, hogy gyűjteményét halálakor a nagyenyedi Református Kollégiumnak adományozta, amely 1849-ben a szabadságharc idején a részben porig égett épületben megsemmisült. ${ }^{41} \mathrm{Az}$ ő testvére Teleki (I.) Sándor guberniumi tanácsos, a református kollégiumok mecénása, Teleki (IV.) József ükapja is könyves ember volt. Deé Nagy Anikó kutatásaiból kirajzolódni látszik az ő személyisége is, s noha Teleki Sándor gyűjteménye nem tekinthető a marosvásárhelyi Teleki Téka alapjának, Teleki Sámuel esetében a könyvek szeretete egészen biztosan az apától ered. ${ }^{42} \mathrm{~A}$ könyvek iránti vonzalom és a gyüjtőszenvedély, a gyűjtés közösségi tevékenységgé szélesítése, a gyüjtő fiainak bevonása tipikusan olyan mintázat, amely a család történetében többször visszaköszön, hiszen Sándor éppúgy örökítette át fiaira a könyvek szeretetét, ahogyan unokája tette dédunokájára, és dédunokája a későbbi Magyar Tudós Társaság elnökére, aki végül is akadémiai könyvtárat hozott belőle létre, ezzel mintegy szimbolikusan is kulturális tőkévé transzformálva nagyapja, apja és saját több évtizedes gyűjtőmunkáját. Teleki Sándornak, és persze később Teleki (II.) Józsefnek, sőt Teleki (III.) Lászlónak is fontos tevékenysége volt a szegény diákok protestáns kollégiumokban való neveltetése és a könyvadományozás gyakorlata. ${ }^{43} \mathrm{Az}$ akadémiai elnök fiaként viselte gondját az elhunyt Kazinczy Ferenc Lajos nevű fiának (1820-1849), akit tragikus módon a szabadságharc leverése után kivégeztek. ${ }^{44} \mathrm{Ez}$ a gyámság egyébként nem az irodalmi vezér iránti tiszteletből eredt. Kazinczy dédanyjának az unokahúga Róth Johanna, Teleki (II.) József felesége volt. ${ }^{45}$

39 Herepei 1971, i.m., 14.

40 Uo., 20-21.

41 Simon Melinda, Szabó Ágnes, Bethlen Kata könyvtárának rekonstrukcioja, Szeged, Scriptum, 1977. Bethlen Kata szerezte meg Teleki II. József számára Bod Pétert nevelőnek. F. CsanaK 1983, i. m., 16. МоNoк István, A müvelt arisztokrata, Budapest, Kossuth, 2012, 30.

42 DeÉ Nagy Anikó, A könyvtáralapitó Teleki Sámuel, Kolozsvár, EME, 1997, 13-22.

43 Uo., 13-22.; F. CSANAK 1983, i. m., 322-330, illetve Tonk Sándor, A Telekiek Erdély történetében = Sáromberke 1319-1994, Kolozsvár, 1994, 165-177.

44 Bona Gábor, Tábornokok és törzstisztek az 1848/49. évi szabadságharcban, Budapest, Zrínyi Katonai Könyv- és Lapkiadó, 1983, 310.

45 Orbán László, Kazinczy Ráday-portéja (kapcsolattörténeti kérdések) = A Ráday-család a magyar kultúrában, Budapest, Ráday Gyüjtemény, 2014, 58. 
Noha Teleki (IV.) József egyenes ági férfi felmenői - követve az erdélyi hagyományokat - lányaikat is igyekeztek taníttatni és előnyösen házasítani, ${ }^{46}$ ők maguk sosem házasodtak náluk magasabb rangú családok gyermekeivel, házassági politikájuk útján mégis gyakran földjükkel határos tulajdonhoz jutottak, amelyek évtizedekkel később a kedvező törvényi feltételek miatt kiváló stratégiai pontok lettek Pest környékén, elsősorban a piacok miatt. A Fónagy Zoltán-féle adattárban, amely az 1780-ig lezajló úrbérrendezés helytartótanácsi tabelláinak feldolgozásán alapszik, Teleki-név alatt 9981 hold található, amelyből 555 hold szerepel az ekkor még fiatal Teleki (II.) József nevén, 5846 hold pedig az ő apjának, idősebb Teleki (II.) Lászlónak a tulajdona volt. Míg László felesége, Ráday Eszter hozománya a 119 holdas gyömrői birtok volt, addig Teleki (II.) Józsefnek az evangélikus Királyfalvi Róth Tamás és Wattay Borbála ${ }^{47}$ lányával kötött házasságával csak a 27 holdas sziráki birtok került a kezébe. Az úrbérrendezés befejeződése utáni évben azonban további 1700 hold örökséghez jutott. ${ }^{48}$ Mivel Teleki (II.) László a hozzájuk hasonló vagyoni helyzetű és felekezethez tartozó, szintén közeli vármegyékben birtokkal rendelkező Ráday családból házasodott, Eszter révén később szintén jelentős birtokhoz juthatott Kishont és Nógrád, valamint Pest vármegyében. Mindkét házasságnak előnye lehetett a közeli birtokállomány is. Teleki (II.) László anyagilag megerősítette a családot, így a birodalom több pontján is kisebb birtokvásárlásokba és kastélyok építésébe fogott. Még apai nagybátyja, Teleki (I.) József kezdte el „Maros ékkövének”, a barokk stílusú gernyeszegi kastélynak az építését. F. Csanak Dóra könyvében felfedi a tervek készítőjének kilétét, $s$ arra is rávilágít, hogy ugyanaz a Mayerhoffer János tervezte a házat, aki a gyömrői kastélyt is. ${ }^{49}$ Teleki (II.) László és felesége az esküvőjüket követően Husztra, majd a gernyeszegi Teleki-birtokra költöztek. A Ráday Eszter révén megörökölt gyömrői birtokokhoz (II.) László fia, a koronaőrként ismertté vált Teleki (II.) József és neje hozzávásárolta még a fent említett birtokot is. ${ }^{50}$ A hat vizsgált generációból kétségtelenül Teleki (II.) Lászlóról tudunk a legkevesebbet. Feltételezhetően rendi ellenzéki szerepvállalásai miatt történhetett, hogy a legmagasabb hivatali pozíciója a guberniumi tanácsosság maradt. Trócsányi Zsolt levéltáros, a Teleki II. Mihályról szóló monográfia szerzője a Teleki portrék című konferenciakötetben

46 Teleki (II.) Mihály legnagyobb lányát például az erdélyi fejedelem unokaöccséhez adta feleségül. Lásd Hereper 1971, i. m., 20.

47 A Wattay vagy Vattay család birtokai meghaladták a 10000 holdat, számos birtokuk volt Pest vármegyében. Lásd FónaGY 2013, i. m., II, 1485.

48 Fónagy 2013, i. m., II,

49 F. Csanak 1983, i. m., 20-21, 404.

50 IVÁNYI 1931, i. m., 14-15. megjelent előadásában felsorolja (II.) László politikai reformkísérleteit, amelyeket azonban sorra megbuktatott az erdélyi rendek konzervatív többsége. ${ }^{51}$ Néhány cselekedete miatt pedig évek múlva fiának kell közbenjárni a Habsburgoknál. ${ }^{52}$ F. Csanak Dóra is megemlíti monográfiája elején, hogy a Telekiek életmódjában az 1750-es évek közepétől áll be változás, vagyis még Teleki (II.) László életében megindult a család életszínvonalának emelkedése, ami ebben az időszakban más, velük közel azonos státuszú család esetében is hasonlóan alakult. ${ }^{53}$

Teleki (II.) László 1778-as halála miatt a kastélyt fia, Teleki (II.) József fejezte be 1792-ben. A koronaőr Teleki József, aki az Akadémia első elnökének nagyapja volt, több szempontból is jelentős személyiség a család életében: ő kezdett el a családtagok közül először irodalommal foglalkozni, ő peregrinálhatott hosszú idő után elsőként, és igyekezett a család magyarországi, mi több, Pest vármegyei jelenlétét erősíteni. A család egyik legnagyobb birtokgyarapítója volt. 1762-ben vette feleségül a Nógrád vármegyei Szirákon élő szász származású Királyfalvi Róth Tamás egyetlen gyermekét, Róth Johannát. E házasság révén József gyakorlatilag másfélszeresére növelte a birtokaik számát. Teleki (II.) László 5846 holddal rendelkezett, összesen 29 birtokán 281 jobbágy, 67 zsellér és 11 hazátlan élt. A tulajdonában lévő területből 2735 hold található Bereg, Bihar, Máramaros és Ugocsa vármegyékben, tehát csaknem a fele volt a Magyar Királyság területén kívül eső birtok. A magyarországi 3111 holdhoz azonban Róth Tamás 1700 holdas, 16 birtokból álló öröksége is hozzákerült, mindehhez aztán később még hozzávásárolt egy 555 holdas birtokot Gyömrőn, tehát a Róth-família révén az ifjú Teleki (II.) József 5366 holddal rendelkező nagy középbirtokossá vált Magyarországon, s immár több föld kötötte az anyaországhoz, mint Erdélyhez. Ilyen előnyök mellett másodlagossá vált a tény, hogy a Róth-család evangélikus volt és nem református, s noha József apja olyan feltételekhez kötötte a házasság engedélyezését, mint például hogy a fia Erdélyben éljen, Teleki (II.) László 1778-as halála után a család véglegesen Szirákon telepedett le, és József gyermekei már itt születtek. ${ }^{54}$

51 TrócsánYi 1980, i. m., 37-38.

52 „Újabb fél év múlva a székely határőrség ügyében tett kijelentései miatt vádolják be Teleki Lászlót, majd Hadik András híreszteli róla, hogy más kérdésekben is az uralkodó akarata ellen szokott beszélni, $s$ kellemetlenségei támadtak a szászok kivételezettsége miatt tett megjegyzései nyomán is." F. CSANAK 1983, i. m., 27.

53 Uo., 8-10. Vö. az ezt megelőző időszakkal: TARNAI Andor, A protestáns polgári müvelödés helyzete = A magyar irodalom története II., A magyar irodalom története 1600-tól 1772-ig, szerk. KLAniczaY Tibor, Budapest, Akadémiai, 1964, 447-454.

54 Vö. Fónagy 2013, i. m., II, 1443; F. CsanaK 1983, i. m., 94-102. Húsz évvel később, 1799ben Teleki (III.) László végérvényesen Pestre teszi át székhelyét. Vö. THaisz András, Gróf Széki Teleki László életírása, Tudományos Gyüjtemény, 1823/1, 87-106. 
Így szerzett a Teleki család olyan birtokot a Magyar Királyság területén, amelyhez Teleki (III.) László és fia, a későbbi Akadémia első elnöke is sokáig otthonaként ragaszkodott. ${ }^{55}$ A sziráki kastély (2. kép) azért vált olyan hamar a Telekiek otthonává, mert a koronaőr József és családja, míg gyermekei kicsik voltak, az év felét mindig Szirákon töltötte a Róth-családtól örökölt birtokán, így Teleki (III.) László nemcsak ott született, hanem az első négy évében ott is élt, érthető hát a későbbi kötődése a birtokhoz. ${ }^{56}$ Nagyapjával, a külföldi egyetemet járt, művelt Róth Tamással igen bensőséges kapcsolatot ápolt; a birtoktól Erdélybe kerülvén első leveleit nagyapjához írta, de egészen 18 éves koráig rendszeresen tartózkodott a kastélyban, ott írta első drámáját is. ${ }^{57}$ A sziráki kötődést erősítette, hogy 1784 ben az evangélikus vallású Teleki Józsefné Róth Johanna a sziráki evangélikus templom közelében felépíttette a család kriptáját, amely azután másfél évszázadon keresztül volt a Telekiek temetkezési helye. Már a Pesten, családja körében elhunyt Teleki (II.) Józsefet is a Róth-kriptába temették el 1796. szeptember 9-én. ${ }^{58}$ Teleki (III.) László legidősebb fia, a családot nem alapító Teleki (III.) Ádám az 1848-49-es események után rangjától megfosztva, betegeskedve szintén Szirákra vonult vissza, és itt hunyt el 1851-ben. Ez persze nem jelentette azt, hogy a família minden tagját itt helyezték végső nyugalomra. A szintén Szirákon született Teleki (III.) József (1777-1817) például a gernyeszegi kriptában fekszik, hiszen a családnak nem minden tagja törekedett a Pest városában való letelepedésre. ${ }^{59}$

A megújuló stratégiák mellett nem lényegtelen a hagyományos gazdálkodásról is ejteni pár szót. 1800 után a Teleki család birtokokkal rendelkezett többek között Szirákon, Gyömrőn, Gernyeszegen, Paszmoson, Sáromberkén, Sorostélyon, Huszton, majd később a Wattay Pál által építtetett pomázi Wattay-kastély is kezükre került. Hogy Teleki (III.) László és fia mennyiben bizonyult jó gazdának, arra kevés adatunk van, mindazonáltal F. Csanak Dóra korábban az apa könyv-

55 BENDA, Soós 1987, i. m., 7. Erról továbbá tanúskodik leveleik keltezése, amelyeken látszik, hogy gyakran tartózkodtak Szirákon. Lásd MNL OL P 654, 36. és 37. tétel.

56 LuKácsy Sándor, Az idösb Teleki László = Teleki és kora (Discussiones Neogradienses 3), szerk. Praznovszky Mihály, Rozsnyó I Ágnes, Salgótarján, Nógrád Megyei Múzeumok Igazgatósága, 1987, 48-55.

57 Teleki László gyermekkori leveles könyvecskéje kéziratban megtalálható a Kolozs Megyei Állami levéltár 928-as fontjában. Jelzete: Arhivele Naționale Romanei Direcția Județeana Cluj (a továbbiakban: ANR DJC) fond nr. 928, crt. nr. 412.; TeLeKI László, Három Szomorú Játékai ugymint Helvetzianak könyü meg-szabadúlása, Senekanak halála, Hunyadi Laszlónak meg-ölettetése, MTAK Kézirattár, RUI $4^{\circ} 133 / \mathrm{I}$.

58 F. CSANAK 1983, i. m., 53

59 VADERNA 2017, i. m., 196 tárában lévő gazdálkodási szakkönyvek meglétével és néhány levélből ismeretes adattal érzékeltette a birtokok modernizációjára való törekvéseket. A majorsági gazdálkodásra való átállás és a birtokmodernizáció az 1820-as években kezdett elterjedni, erre Esterházy Miklós tatai és gesztesi uradalma kapcsán Szabad György monográfiájában, valamint a Festetics uradalom kapcsán láthatunk példát, ${ }^{60} \mathrm{a}$ Telekiek azonban jóval szerényebb mennyiségű birtoktesttel rendelkeztek. Annyi bizonyára kijelenthető, hogy ha ebben is folytatták Teleki (II.) József munkálkodását, akkor minden valószínűség szerint nyitottak voltak a fejlesztésekre. A szóba jöhető uradalmakra vonatkozó források ismerete nélkül ugyan nem jelenthetjük ki bizonyosan, hogy ez (III.) László idejében is így volt, de a családi könyvtárban viszonylag széles választékban olvashattak gazdálkodási szakirodalmat az 1740-es évektől fogva ${ }^{61}$ Igaz ugyan, hogy László gyűjtési stratégiája eltért apjáétól, hiszen ő nem csupán a saját érdeklődésének megfelelően vásárolt könyveket, hanem részletes szakrend szerint gyűjtött, de természetesen ismerte, vagy legalábbis tudott a könyvtárában lévő kötetekről. Így például Johann Wiegand $A z$ ausztriai paraszt ifjuságot a jól rendelt mezei gazdaságra oktató kézi könyvecske Szilágyi Sámuel fordításában 1774-ből, Tessedik Sámuel evangélikus lelkész A’paraszt ember Magyar Országban címủ 1784-ben németül megjelent könyvének Kónyi János által 1786-ban kiadott műve is szerepel a könyvtár egyetlen ránk maradt kéziratos katalógusában. Szuhányi János Szorgalmatos méhész című kötete 1795-ből, Baróti Szabó Dávid Paraszti majorság című könyve 1779-80-as kiadásban, L. Junius Moderatus Columella művei 1819-es magyar fordításban Nemes Fábián Józseftől, Pethe Ferenc Pallérozott mezei gazdaság... című művének mindhárom kötete szintén megtalálható volt Teleki (III.) László könyvtárában, ugyanúgy, mint Prileszky Pál uradalomigazgató jogismereti kötetének egy 1740-es évekbeli és egy 1783-as kiadása. Berzeviczy Gergely evangélikus egyházkerületi felügyelő, közgazdasági szakíró két kötete is olvasható a katalógusban, és Rudolph Witsch Útmutatás. . című kiadványa 1809-ből, Vályi András Magyarországnak leirása, Ercsei Dániel és Schwartner Márton Statisztikája is rendelkezésre állt. Utóbbiért a szerző magyar nemességet kapott, jóllehet negatív színben tüntette fel a magyar kulturális életet, megsértve ezzel több szerzőt, akik aztán támadták is őt a Tudományos Gyüjtemény

60 SZABAD 1957, i.m. és SzÁNTó Imre, Keszthely úrbéri viszonyai a Festeticsek földesurasága ide jén 1739-1848, Szeged, Acta Historica, 1984.

61 „Ezekben ma összesen 87 növénytani és 142 állattani Teleki-kötet található, de a 19. századi mennyiség ennél bizonyosan nagyobb volt, mert a régi szakrend szerint elhelyezett könyvek egy részét azóta máshová tették, illetve több darab ma már nincs a könyvtár tulajdonában." egy részét azóta máshová tették, illetve több darab ma már nincs a könyvtár tulajdonában." zású botanikai és zoológiai könyvei, Magyar Könyvszemle, 2018/4, 403. 
folyóirat hasábjain. ${ }^{62}$ Szintén megtalálhatóak voltak a könyvtárban Pethe Ferenc saját művei, valamint Pethe 1815-ben megjelent fordításában Humphry Davy $A$ földmivelési kimia gyökere egymásból folyó letzkékben címü könyve. Számos más hasonló tárgyú kiadvány is a gyűjtemény részét képezte, és már ebből a felsorolásból is látszik, hogy Teleki (II.) József gyüjtési időszakából is jelentős számban származtak könyvek, és fia, (III.) László élete végéig gyűjtötte a mezőgazdasági szakirodalmat. ${ }^{63}$ Mindemellett a grófok gyermekeiket gazdasági-hivatali gyakorlatra is oktatták. Erre utal, hogy Teleki (III.) László 18-21 éves kora között nemcsak drámákat írt és könyvkatalógust másolt, hanem ugyanabban a letisztázott, családi nyilvánosságban keringő kéziratos kötetben számadásra, könyvelésre nézve is demonstrálta tudását. Feltételezhetően az apa előtt kívánta bizonyítani rátermettségét, ahogy ez az 1785-ben apjához eredetileg latin nyelven írt leveléből is kitűnik: „Mindemellett hogy azon írásnemnek is, amely a közügyeket illeti, tanúsítványát bírhasd tőlem, e nyolc gyakorlatot is, három táblázattal együtt, csatolom. Láthatod ezekből, hogy akár a stílusban, akár a gazdasági tudományokban attól az időtől kezdve, mióta itt vagyok, mennyi előrehaladást tettem.” ${ }^{64}$

Teleki (II.) József (3. kép) egyik komoly szenvedélye volt az építkezés. Ő fejezte be a család gernyeszegi házát, felügyelte a sziráki palota átépítését, nevéhez füződik a gyömrői kastély építése is. Noha már a türelmi rendelet előtt megkísérelte, hogy Pesten telket szerezzen, vételi szándékát a birodalom elutasította. ${ }^{65}$ Néhány évvel később azonban az 1781-es türelmi rendelet lehetővé tette a Pestre költözést azzal a feltétellel, hogy a protestánsok és ortodox vallásúak templomot és maguknak házat építhettek Pesten, s hogy katolikus szertartásokon való részvétel és dekretális eskü nélkül is hivatalt viselhettek a Helytartótanácsnál, amely 1784-ben költözött Budára. ${ }^{66} \mathrm{Ez}$ a rendelet a protestáns nemesség számára új karrier- és vagyonszerzési lehetőségeket jelentett a 19. században, és később valóban növekvő létszámban

62 Czifra Mariann, Kazinczy Ferenc és az ortológusok, Budapest, Ráció (Ligatúra), 2013, 81-85.

63 Ami még Teleki (II.) Józseftől maradt meg: Simon Philibert de la Salle d’Etang, Manuel d'agriiulture, Párizs, Lottin - Dessain, 1764; Ludwig MitTERPACHER, Elementa rei rusticae, Buda, 1777; LIppay János, A Posoni kert, Győr, 1753. Ami pedig valószínűsíthetően Teleki (III.) László gyüjtése: HAjós Sándor, A mezei gazdaságnak különös formája és annak rendes számolása. Székesfehérvár, 1819; Kováts Antal, Utasitás a fák betegségeiröl, gyógyitásairól és a természet mivoltáról, munkáiról, Marosvásárhely, 1809; SzuHÁNyI János, Szorgalmatos méhész, Pest, 1795.

64 Lásd a kötetben apjához írott latin nyelvü, Göttingenben kelt levelét. TeLEKI László, Péter Király..., MTAK Kézirattár, RUI $4^{\circ} 42$.

65 F. CSANAK 1983, i. m., 42.

66 A rendelet magyar fordításban: Sinkovics István, Magyar történeti szöveggyüjtemény II, Budapest, Tankönyvkiadó vállalat, 1968, 1045-1053. képviseltették magukat a kormányszervnél, így hivatalaik már nem kötötték őket szorosan Erdélyhez. ${ }^{67}$ Ez a törvény a Telekiek közül leginkább az akadémiai elnök Teleki (IV.) József előtt nyitott igazi utat hivatásszerủ hivatalviselés betöltésére A legfelső politikai elitpozíciók (nádor, tárnokmester, országbíró, kamaraelnök, személynök) számára is elérhetetlenek maradtak, ${ }^{68}$ örökletes fönemesi címük mellett ugyanis nem rendelkeztek óriási uradalmakkal, több ezer jobbággyal és a magyarországi kapcsolatrendszerük sem a régi elithez, hanem az újonnan felemelkedőkhöz kötötte a családot. Maradtak tehát a nagy középbirtokosokat megillető rendi jellegű hatóságok: a Helytartótanács, a Kúria, a Kamara és a Kancellária. A koronaőr Teleki (II.) József 1790-ben a protestánsok nádorjelöltjeként teljesen esélytelennek számított ugyan a katolikus többségű országgyűlésen, de a kötelező protestáns jelöltállítás miatt részt vett a nádorválasztáson. ${ }^{69}$ Ellenben mégis gesztusértékű, hogy ő volt a protestáns párt jelöltje, mert mutatja a család felekezeten belüli tekintélyét is. Az 1791. évi országgyűlésen a vallásügyi törvénycikk beiktatása körül zajló felekezeti harcok, amelyekben a koronaőr Teleki is kitartóan részt vett, jól mutatják, hogy míg „a felekezetiség a 18. század folyamán szűnt meg döntő szempont lenni a magyar politikában," ${ }^{70}$ addig a hivatalviselésben ez csak valamivel később következett be. A protestánsok oktatási reformjai, valamint a felettük való katolikus ellenőrzés, amely ellen Teleki (II.) József hevesen harcolt, ${ }^{71}$ épp azért lettek jelentősek, mert a 18. században is rohamosan nőni kezdett a hivatali ügyintézés iránti igény, s a kellő számú, megfelelő oktatásban részesülő protestánsra szükség is lett a 19. század elejétől fogva. Ők aztán a hivatalok utánpótlási bázisaként az így szerzett hivatalaik által nemcsak stabil megélhetésre, hanem olyan kapcsolathálóra és szervezeti működésben elsajátított gyakorlati tudásra tettek szert, amelyet később különböző társas intézményekben, így az Akadémiában is kamatoztatni tudtak. ${ }^{72}$ Ennek az új, a 18. század közepétől fogva fokozatosan erősödő hivatali fönemességnek ${ }^{73}$ lett a tagja Teleki (IV.) József is az 1820-30-as években.

67 Ember Gyözö, A M. Kir. Helytartótanács ügyintézésének története 1724-1848, A M. Kir. Országos Levéltár kiadványa, 1940, 83.

68 Cserpes Tünde, SzIJÁrtó M. István, Nyitott elit? A magyar fóméltóságok a 18. században, Századok 144 (2010), 1225-1261.

69 Szijártó M. 2017, i. m., 378-379.

70 SzIJÁrtó M., A kora újkori magyar rendiség az újabb szakirodalomban II., Aetas, 24 (2009) 4. sz., 131.

71 F. CSANAK 1983, i. m., 253-260

72 Erről részletesen lásd KolLÁR Zsuzsanna, Mintaadó szervezeti formák a Magyar Tudós Társaság müködési rendjében, in: Aranka György és a tudomány megújuló alakzatai, szerk. BIRó Annamária, Egyed Emese, Kolozsvár, EME, 2018, 279-298.

73 Vörös Károly, A társadalmi fejlödés fơ vonalai, in: EMber Győző, Heckenast Gusztáv (szerk.), Magyarország története, 1686-1790, in: Magyarország története tiz kötetben, 4. kötet, föszerk. PAcH Zsigmond Pál, Budapest, Akadémiai Kiadó, 1989, 682-683. 
Teleki (III.) László még inkább csak a törvényből és rangjából adódó lehetőségekből profitálhatott, ugyanakkor új típusú jövedelemszerzési lehetőségként megjelent a pesti és budai bérpalota-építés, amelynek kivitelezésére a Teleki család az elsők között vállalkozott már akkor, amikor még közel sem volt egyértelmű, hogy mennyire válik ez majd jövedelmezővé Pesten. 1787-ben a koronaőr József egy katonai árverésen megvásárolta a budai Szent György téri telket, amelyen 1789-ben fejeződtek be az építési munkálatok. ${ }^{74}$ (4. kép) Ez az épület pompázatos copf-stílusú bérpalota volt, az első bérpaloták között volt Budán, és nem a család hivatalos rezidenciájául szolgált, így jelentősen növelte a család bevételeit annak ellenére is, hogy a nemesi adómentesség nem terjedt ki a városi ingatlanokra. ${ }^{75} \mathrm{Az}$ első pesti telekaukció 1789-ben zajlott le, és 1793-ig 134 telket értékesítettek - feltehetően ekkor vásárolta első pesti telkét a koronaőr József is. Az 1793 és 1796 között épült Szervita téri Teleki-palotába azonban 1796-ban bekövetkezett halála miatt ő már nem költözhetett. ${ }^{76}$ Mindeközben 1795-ig befejezte a Kolozsváron 1792-ben férfi utód nélkül elhunyt Teleki (II.) Ádám (1740-1792) házát is, ez az épület ma is központi helyet foglal el a városban. Teleki (II.) József volt tehát, aki Erdélyből „kivándorolt”, hogy a fejlődő pesti-budai kulturális-politikai vérkeringésbe bekapcsolódhasson. Saját ízlését és érdeklődését reprezentáló jelentős könyvgyüjteménye ismeretes, tudjuk azt is, hogy vonzódott az utazáshoz, a színházhoz és az építészethez (több mint nyolc épület felépíttetése füződik a nevéhez). Ugyanakkor az általa betöltött pozíciókat utódai is messze felülmúlták mind politikai, mind pedig tudományos téren, aminek elsősorban az új típusú intézményekben bekövetkezett tekintélyszerzés volt az oka.

Noha számos analógiát találunk Teleki (II.) József és fia, (III.) László életútja között, kezdve a könyvgyűjtés szeretetétől az irodalomhoz való közös kapcsolatukig, László politikai tekintetben fóképp az 1785-1789-es években a rendi ellenzék táborát gyarapította, így az udvarban és Magyarországon ekkortájt jelentős bizalmi pozíciókra nem tarthatott számot, annak ellenére sem, hogy társadalmi

74 F. CsanaK 1983, i. m., 41-43 és 428.

75 То́тн Árpád 2009, i. m., 86.

76 Néhány évtizeddel később a bérházépítés nemcsak nagybirtokosok, hanem kereskedők, bankárok, magas rangú hivatalnokok számára is kiugróan jövedelmező befektetési formává vált, szemben az alig 4\%-os hozamú birtokjövedelmekkel, a pénzkölcsönzéssel vagy a bizonytalan államkölcsönökkel. Lásd $A$ város társadalma címủ fejezetet, in: BácsKaI Vera, KuBinYI András, GYÁnI Gábor, Budapest története - a kezdetektöl 1945-ig, szerk. Nyerges András, Budapest, BFL, 2000, 103; BÁcsKaI Vera, Városok és városi társadalom Magyarországon a XIX. század elején, Budapest, Akadémiai, 1988; KaвDEBó Gyula, A városok épitése: 1. Budapest. Városi Szemle, 1908/2, 95-103. gyarapodásával egy időben apjához hasonlóan ő is a lojalitás felé mozdult el. 1789ben kezdte meg hivatali emelkedését az erdélyi kormányszéknél, 1791-től kamarai tanácsos, rá egy évre az erdélyi Királyi Tábla bírája lett - 1799-ben azonban végleg lemond erdélyi tisztségeiről. Jól jellemzi karrierstratégiáját, hogy peregrinációja alatt konzervatív apja rosszallása ellenére is beáll a bécsi szabadkőművesek táborába, ${ }^{77}$ aztán 1790-ben az első olyan förangúak közt van, akik szokatlan módon, arisztokrata voltuk ellenére vármegyei követté választatták magukat. Korábban e funkció miatt a rendi alkotmány a szokásjog szerint kizárta volna őket a felsőtáblán való megjelenésből, ebben az időben azonban már az alsó- és a felsőtáblán is megjelenhettek. Ráadásul Teleki (III.) László mindezt a mindig is ellenzéki szerepben álló Máramaros vármegyében tette. ${ }^{78}$ Tudva, hogy a 18. században az alsótábla egyre jelentősebb súllyal van jelen, és ez a csoport képviseli az ellenzéket az országgyülésen az aulikus förendekkel szemben ${ }^{79} \mathrm{ez}$ a lépése igencsak elgondolkodtató. Egyes értelmezések szerint a 18. században számos alsóházi követ jelent meg az országgyülésen a fórendek „kreatúrájaként” azzal a céllal, hogy politika viharokat szítsanak. ${ }^{80}$ Akár ez a lehetőség is elképzelhető lenne, de az alsóházi részvétel semmiképpen sem illeszkedik a hagyományos förendi politikai stratégiák sorába, sokkal inkább a bene possessionati felemelkedésének logikája jellemzi. ${ }^{81}$ László tehát sok szempontból követte a családi hagyományokat, ám bizonyos területek és döntések esetében nem félt a normától való eltérésektől sem.

Ezt igazolja házastársához, gróf Teleki Máriához való viszonya is. Az unokatestvérével kötött házassága megerősítette a család erdélyi kötelékeit, de a házasság felbontását illető terve meglehetősen szokatlan: a reformátusoknál a válás engedélyezett, mégsem volt gyakori jelenség. Fekete János (Teleki László barátja) Teleki Mária halála után László gyászán élcelődve azt is felvetette, hogy a haláleset a grófot nem rázta meg olyan mértékben, ahogyan azt gyászbeszédében és verseiben

77 F. CSANAK 1983, i. m., 345-347.

78 Szijártó M. István, A diéta, Budapest, Osiris, 2005, 439.

79 Uo., 151, valamint a 4.b fejezet.

80 Horváth Mihály, Magyarország történelme VII. 116-118, 362-363; Ember Győzö, A barokk rendi társadalom = Barokk és felvilágosodás, szerk. Domanovszky Sándor, Budapest, 1941 (Magyar múvelődéstörténet, 4), 146; WELLMANN Imre, Rendi állás és hivatali rang a XVIII. század eleji kormányhatóságokban, Levéltári Közlemények, 1940-1941/18-19.

81 SziJártó M. 2005, i. m., 18. 
artikulálta. ${ }^{82}$ Újabb szokatlan döntést hozott, amikor elvette a nála húsz évvel fiatalabb báró Mészáros Johannát, aki később József nádor feleségével közeli kapcsolatokat ápolt, és komoly mecenatúrát mozgósított az 1830 -as években. ${ }^{83}$ Apja és felesége halálát, illetve 1801-ben bekövetkezett újraházasodását követően 1803ban, harminckilenc évesen lett a magyar országgyűlés királyi táblájának bírája. ${ }^{84}$ 1802-től a Dunamelléki Református Egyházkerület világi főkurátora, 1811-től a Somogy megye adminisztrátora tisztségeket is betöltötte. Később, halála előtt másfél évvel a hétszemélyes tábla bírája lett.

Teleki László vagyonának nagy részét gyermekei nevelésére fordította, szabad idejében költészettel foglalkozott, ${ }^{85}$ és nem utolsó sorban egész életében gyüjtötte a könyveket. Már apja 1796-ban bekövetkezett halála előtt is rendelkezett Kolozsváron saját könyvgyüjteménnyel. Ezt igazolják azok a kéziratos könyvkatalógusok, amelyek néhány éve kerültek elő a Kolozs Megyei Állami Levéltárban. ${ }^{86}$ Érdekes kölcsönzési adatokra bukkanunk a legnagyobb jegyzék hátuljában. A katalógust 1795 és 1799 közt használták a kölcsönzések feljegyzése végett. A kölcsönző személynek be kellett írnia a dátumot, a kikölcsönzött könyvek címét és alá is kellett írnia a jegyzéket. 15 kölcsönzésről van írásos adat, ebből hét ki van húzva, amiből arra lehet következtetni, hogy a könyvek visszaszolgáltatásakor a bejegy-

82 „De tán a' Satyra, mert nevetni szeret, Azt mondná, hogy azért irhattál ezeret, Mert érte szivedet nem igen rongálta Fájdalom, 's tsak szokás versidet dictálta; 'S Minthogy mindeneket, hogy zokogni látszál, Fel keresni kivánsz: versed Tonussá vál." Az MTA KIK-ben lévő kéziratot közli: VADERNA Gábor, Gróf Teleki László és gróf Teleki Mária válási kisérlete és irodalmi visszhangja, Lymbus, 2018, 495-512. Vö. VAderna 2017, i. m., 187-193.

83 Tótн Árpád, Önszervezö polgárok, Budapest, L’ Harmattan, 2005, 61; Gyular Lajos, „....) barátom a túlvilágon is" Döbrentei Gábor és gróf Gyulay Lajos naplófeljegyzései (1835. május Tanszék, 2011.

84 „A királyi tábla az alsótáblának nemcsak egyik alkotórésze, hanem afféle tisztikara volt. Ezért nemcsak hogy részt vett az alsótábla által kiküldött minden egyes bizottságban, de ezt nem is csekély súllyal tette." SziJérTó M. 2005, i. m., 161.

85 Voinovich Géza, Idösb gróf Teleki László irodalmi munkássága, ItK, 1899/2, 129-167.

86 Catalogus librorum Ladislai Teleki, Romániai Kolozs Megyei Állami Levéltár, ANR DJC fond nr. 928 crt. nr. 470: Nagy tizenkettedrét méretű, tematikus jegyzék, több kéz írása, 18. századi, négyszintủ részletességủ szakrend szerinti. A legkésőbbi benne szereplő tétel 1796-os. 249 számozott fólió, 3056 tétel. A papír a holland Zaandyk városában 1675-től 1902-ig mủködő Cornelius és Jan Honig nyomdászattól való, a vízjelen egy postakürt szerepel koronás pajzson. Catalogus Librorum 1217, ANR DJC fond nr. 928 crt. nr. 472: Ez egy negyedrét méretủ alfabetikus jegyzék. Catalogus Librorum Ladislai Comitis de Teleki, London, 1787 die. 20. Juni, ANR DJC fond nr. 928 crt. nr. 415.: Szintén negyedrét méretủ alfabetikus jegyzék, a szerzők vezetékneve szerinti rendezéssel, A-tól L-ig tart, 193 tételt tartalmaz. Ebben találhatók a Teleki László peregrinációja alatt Angliában vásárolt könyvek. zést áthúzták. Filozófiai köteteket, illetve Fesslert, Lessinget, Prayt, Schwartnert kölcsönöztek a jegyzék tanúsága szerint. 1796. január 13-án Wesselényi József például Ignaz Schmidt Neuere Geschichte der Deutschen című 1785-ben kiadott kötetét kölcsönözte ki, Wesselényi Farkas Friedrich Gentz Betrachtungen über die französische Revolution című kötetét. Aranka György a 16. századi Alpinus Prosperus itáliai fizikus és botanikus híres művét vette kölcsön, amely a prognózishoz szükséges számos betegségtünetet tartalmaz, amelyek lehetővé teszik a páciens várható élettartamának megállapítását. ${ }^{87} \mathrm{Az}$ ilyen felbukkanó források, mint amilyen a kölcsönzések listája, sokat elárulnak az erdélyi nemesség kapcsolatfelvételéről, ahogyan az is, hogy a könyvek később is Kolozsváron maradtak, távol tulajdonosuktól, talán az ott tartózkodó fiainak tanulása céljából. Szabó András, a Teleki gyerekek nevelője gondját viselte és szakrend szerint felállította a könyveket, ő adott nekik hosszas munkálatok árán könyvtárformát $1806-$ ra ${ }^{88}$ Baló Sámuel pedig a beszerzők egyike volt. ${ }^{89}$

Irodalomtörténetünk leginkább ortológusként emlékezik meg Teleki (III.) Lászlóról: nyelvészeti tárgyú dolgozatokat publikált, melyek közül az első jelentős A' magyar nyelv elé mozditásáról buzgó esdeklései címü volt 1806-ban, ${ }^{90}$ a szerző ekkor már negyvenkét éves. 1819-ben - tizenhárom évvel e kötet megjelenése után - fia, Teleki (IV.) József az előírásoknak megfelelően név nélkül benyújtja szintén nyelvészeti tárgyú pályázatát az 1815-17. évi Marczibányi István-féle alapítvány jutalomkérdéseire. József a pályázatot megnyerte, s nevének felfedésekor apja döbbent meg a leginkább, hiszen ő volt ekkor az alapítvány elnöke. ${ }^{9}$

87 Prosper Alpinus, De praesagienda vita et morte aegrotantium (1601). E könyv 1733-ban Leidenben kiadott egyik példánya szintén megtalálható ma a Teleki-gyújteményben. Érdekesség, hogy a könyvet még a 20. században is többször újra kiadták.

88 Szabó András Teleki Lászlóhoz Kolosvár, 1802. február 7. MTA Kt. M. Irod. Lev. 4Rét 11. és 12. ImRe Sándor, Wesselényi Miklós ismeretlen nevelöi, Erdélyi Helikon, 1930/5, 389-395.

89 Baló Sámuel Teleki Lászlóhoz, MTA Kt. M. Irod. Lev. 4Rét 22.

90 TeLEKI László iff. Leveles könyvecskéje, Romániai Kolozs Megyei Állami Levéltár, fond 928, 412; Uö, Vallás, babona, hitettenség, Kolozs Megyei Âllami Levéltár, fond 928, 37.; UO, Gyermekeim neveléséröl való gondolataim, Kolozs Megyei Állami Levéltár, fond 928, 480 Uó, Péter Király (...), MTAK Kézirattár, RUI 4 42; Uö, Három Szomorú Játékai, MTAK Kézirattér, RUI $4^{\circ}$ 133/I; A' magyar nyelv elé mozdításáról buzáó esdeklései $G$. Teleki Lászlónak, Pesten, Trattner Mátyás' betủivel, 1806. Elsőként a buzó esdeklései” jelent amely Kultsár István kérdéśre ́́d amely Kul A Ist be múvét. A jutalomkérdés elozzménye az 1805 . évi IV. törvénycikk a magyar nyelv hasznà-
latáról.

91 Szabó Ádám, Teleki József (1790-1855) tudományos jelentösége, Marosvásárhely, Teleki Téka Alapítvány, 2018, 220. 
Teleki József karrierje az apja által megkezdett munkának mintegy a folytatása volt. Mindketten koruk legnívósabb független tudományos társaságának elnökei lehettek, és mindketten úgy kapták meg e kinevezést, hogy egyaránt elismertek voltak hivatali pozíciójukban és tudományszervezőként. Teleki László 1816-ra olyan tekintélyre tett szert literátorként, hogy Pest vármegye őt delegálta a Marczibányialapítvány elnöki székébe. E tisztségét élete végéig viselte, ám halálával az alapítvány munkája is hanyatlani kezdett, mert Cziráky Antalból és Végh Istvánból már hiányzott az ügyszeretet. ${ }^{92}$ Teleki László alapítványi munkája mellett vacsorákat adott Pesten a Szervita téri palotában, a nyelvújításban is szerepet vállalt, és annak megoldását egy tudós társaság megalapításában látta. A börtönből szabadult Kazinczy Ferencet, akit még apja révén ismert meg, visszavezette a közéletbe, és személyét legitimálta. Kazinczy úgy küldte el a Tudományos Gyüjtemény kiadójába Orthologus és Neologus címủ munkáját, hogy Teleki Lászlónak címezte, és arra kérte, a dolgozatot adja át Thaisz András főszerkesztőnek. (Thaisz egyébként a Telekiek ügyvédjeként dolgozott, emiatt a korábbi szakirodalomban felmerült, hogy az egész Tudományos Gyüjtemény Teleki László fennhatósága alá tartozott.) $)^{93}$ Czifra Mariann Telekivel kapcsolatos észrevétele szépen illusztrálja, miképpen volt összehangolva a rendiség tekintélyelvű hierarchiája a tudományos pozíciókkal. Figyelemre méltó, hogy a Tudományos Gyüjtemény 1819. októberi számában az idős Teleki László hétszemélyes táblai előléptetését - más tudományos előmenetellel rendelkező hivatali és egyházi személyek előmenetelével együtt - literátori munkásságára hivatkozva közlik:

„Ő Császári Királyi Felsége meg lévén arról győződve, hogy tsak azon Ország boldog, mellynek Tudománykedvellő, Igazságszerető, bölts Elöljárói vagynak; kedves Hazánk eránt való atyai gondoskodásának új példáit adta e’ következendő Előléptetésekkel: (...) Hasonlóképen Méltóságos H. Sz, B, Gróf Széki Teleki Lászlót, az elfelejthetetlen Gr. Teleki Jósef’ fiát Cs. Kir. Kamarást, Nemes Somogy Vármegye Fö Ispány Helytartóját, és a’ Tekintetes Kir. Törv, Tábla’ Báróját, a’ ki ditsö mind Atyának nyomdokit követvén, mind a’ Hazai, mind a' Romai mind pedig a’ mai Külföldi Literaturában magának jeles érdemeket szerzett, 's ezen Tud. Gyüjteményünket nem csak Előfizetéssel mozdítja elő, hanem e’ f. e. 1-ső Kötetbe iktatott betses Értekezésével megtisztelte, ugyan a’ N. M. Septemvirális Táblának Assessorai közzé iktatni méltóztatott." ${ }^{44}$

92 KeRÉNYI 2002, i. m., 80-83.

93 Czifra 2013, i. m., 39-41, vö. Bíró 1994, i. m.

94 THAIsz András, Elölépések, megtiszteltetések, Tudományos Gyüjtemény, 1819/10, 119-120
Vitatható persze, hogy az uralkodó csakugyan figyelembe vette-e az előléptetéskor az ilyen irányú tevékenységet, kivált A’ Magyar Vers-szerzés Mesterségéröl szólló Gondolatai Gróf Teleki Lászlónak című értekezést. ${ }^{95}$ Ha csupán Thaisz András föszerkesztőnek a tiszteletnyilvánításáról van szó, akkor is érdekes, hogy ez a fajta tudományosságot méltató beszédmód az országos nyilvánosság részét képezi. Ráadásul a későbbi évtizedekben a tudományos tevékenység és a politikai befolyás, a rang ugyanilyen fokú összemosódása, keveredése jellemző lett, legalábbis a Magyar Tudós Társaság tiszteletbeli tagjává váló férfiak közül sokan inkább csak a „tudós hazafi” címet kaphatnák meg, mert a valódi tudományos kutatómunkát nem ők végezték. 1823-ban, halála után két évvel Thaisz András megjelentette Teleki (III.) László arcképét és életrajzát néhány versrészlettel együtt a Tudományos Gyüjteményben. A következő szavakkal összegezte megemlékezését:

„Egy illyen Férfitól foszta meg a’ zordon halál (...) hasznos és példás életének 57-ik esztendejében, közhasznú fáradozásainak idő előtt véget vetvén, ’s ez által kedves Háza népét, a’ Vallást, a' Hazát, de főképpen a’ Magyar Literaturát, mellynek minden Mágnások biztató példájául szives és lelkes barátja, betsülője, 's elömozdítója volt (...)" ${ }^{96}$

Teleki halálakor ügyvédje, közeli barátja ebben a terjedelmes életrajzban a gróf életét, irodalom iránti szenvedélyét és tevékenységét jelentőségteljes életútként ábrázolja, melyben minden a tudománypártolásért történt. Míg a Tudományos Gyüjtemény első pár évében főként foúri mecénások képei jelennek meg - jó példa erre Teleki Lászlónak az 1823. januári szám elején közzétett arcképe is -, addig a Magyar Tudós Társaság évkönyveiben olyan prominens személyiségek örökíttetnek meg, mint Kölcsey, Kazinczy vagy Berzsenyi. S ha már a tudománypártolás e Telekinél előkerülő sajátos módját vizsgáljuk, nem lehet szó nélkül hagyni, hogy az Akadémia történetét elsőként megíró Döbrentei Gábor miképpen illeszti be az első elnök apját, Teleki Lászlót az Akadémia megalakulásáról szóló előtörténetbe. Döbrentei ugyanis, hasonlóan Thaisz Andráshoz, Teleki László tudományos szervezetekben megszabott szerepléseinek előzményeként tartja számon az Erdélyi Nyelvművelő Társaság utódtársaságában megszabott pénztárnoki pozícióját. ${ }^{97}$ Szintén említésre érdemes, hogy a Tudományos Gyüjtemény 1818. évi 3. számában az 1817. évi november 23-án a Nemzeti Múzeumban tartott Magyar

95 Teleki László A’ Magyar Vers-szerzés Mesterségéröl szólló Gondolatai Gróf Teleki Lászlónak, Tudományos Gyüjtemény, 1819/1, 17-49.

96 Thaisz András, Gróf Széki Teleki László életirása, Tudományos Gyüjtemény, 1823/1, 87-106.

97 Döвrentei Gábor (szerk.), A Magyar Tudós Társaság Évkönyve, 1833, 35. 
Nyelv Ünnepe alkalmából elmondott beszéde teljes terjedelmében megjelent. Ezt a beszédet Teleki László a Marczibányi-alapítvány elnökeként mondta el. ${ }^{98}$ Erről a tisztségéről 1833-ban a Magyar Tudós Társaság első évkönyvében Döbrentei azt írta egy lábjegyzetben, hogy „Pest Vármegye választottságának Elölülőjévé József Főherczeg, Nádor és Főispán, Gróf Teleki Lászlót nevezte”. ${ }^{99}$ Döbrentei tehát az első megírt akadémiatörténet egyik jelentős állomásává tette Teleki László irodalmi működését azáltal, hogy tevékenységét az alapítás előzményei között ilyen előkelő helyen tünteti fel, $\mathrm{s}$ az is kiderül belőle, hogy József nádor (5. kép) nevezte ki az apát is, ahogyan később (IV.) Józsefet is ő jelölte ki az Akadémia élére. Az a József nádor, akit László akadémiatervezetében a protektori teendőkre javasolt. ${ }^{100}$

László munkáját és szemléletét nemcsak fia, de második felesége, gróf Teleki Lászlóné báró Mészáros Johanna is tovább vitte. Tekintélyét jól mutatja, hogy felette 1843. március 18-án maga Toldy Ferenc mondott gyászbeszédet az Akadémián. Ezzel a gróf özvegye volt az első és sokáig egyetlen asszony, akiről az Akadémiában halálakor megemlékeztek. ${ }^{101}$ Az özvegy egyrészt egyedüli nőként adakozott a Magyar Tudós Társaság felállításakor, másrészt „a nőegyesület által alapított intézetek, és különösen az ápolóintézet, a szabad dolgozó ház, a szegények iskolája s a senyvedők háza jövendőjét $s$ szebb virágzását úgy vélte teljesen biztosíthatónak, ha azok egy saját, arra alkalmas épületben, közös felügyelés alatt összesíttetnek.” Erre a célra egy 138000 pengő forintos épületet vásárolt meg hitelre, és ajánlotta fel azt a vármegyének, hogy abban közös intézet Josephinum néven állíttasson fel. ${ }^{102}$ Teleki Lászlóné olyan vagyonokat áldozott az 1817-ben alapított Pesti Jóltévő Asszonyi Egyesület munkájára, hogy 1833-ban már a családja és maga a nádor kérte, adja át az egyesületet a Helytartótanácsnak, „mivel ő addigra a vagyona nagyobb részét feláldozta az egyesület javára." ${ }^{103}$ Teleki (IV.) József pedig - nem lévén utódja, kinek révén a család társadalmi kapcsolatait szélesíthetné - életművén és a család könyvtárán felül a saját, tetemes vagyonát is az Akadémiára hagyta. E gesztusok is illusztrálják, hogy a tudományos vagy tudománypártoló tevékenység értelmezése ebben az időszakban egyaránt jelentette a haza előmenetelét szolgáló munkát is. Úgy is fogalmazhatnánk, hogy az irodalmi

98 A levél itt található: Kultsár István, Szóllás..., Tudományos Gyűjtemény, 1818/3, 57-65. 99 Uo., 42.

100 A magyar nyelv elé mozditásáról buzgó esdeklései G. Teleki Lászlónak, Pest, 1806, 153-210.

101 Kiad. BAjZA József, Toldy Ferenc irodalmi beszédei, Pozsony, Wigand Károly Frigyes betűivel, 1847.

102 Uo., 94.

103 Tóтн Árpád, Önszervezö polgárok, Budapest, L' Harmattan, 2005, 61. és politikai-társadalmi cselekvést a közvélemény nem választotta el, ahogyan ekkor még a szépirodalom sem vált ki az osztatlan literatúra-fogalomból. A jelenség megítéléséhez további kutatásokra és példákra lenne szükség, innen nézve mégis érthetőnek tűnik, milyen szerepe volt a család stratégiájában a tudományos előmenetelnek, amely aztán Teleki (IV.) József pályáján érte el csúcsát.

\section{„Ettől a Telekitől sokat várok.” ${ }^{104}$}

Teleki (IV.) Józsefről meglepően kevés ismerettel rendelkezünk. Monográfia még nem készült életéből, részben talán mert az irodalomtörténet-írás szempontjából érdekes forrásdokumentumok, mint például útinaplója (Tagebuch einer im Jahr 1812. den 9. April unternommenen Reise), a második világháborúban megsemmisültek. ${ }^{10}$ Szépirodalmat sosem írt, magánéletéről keveset tudunk, kultusza nem alakult ki, noha halálakor voltak erre irányuló kísérletek. ${ }^{106}$ Irodalmi mủködése inkább jellemezhető olyan háttértevékenységként, amelynek megértéséhez elszórtan megtalálható források felkutatása, társadalom- és mikrotörténeti vizsgálatok lennének szükségesek. Gyermekkoráról leginkább Teleki (III.) László és Szabó András levelezéséből ismerhetünk meg részleteket. Jelen dolgozat keretei miatt itt most csak egyetlen, fontos példát említek: 1807-ben Szabó bérletet vásárolt a Teleki-gyerekeknek a Pest-Budára érkezett erdélyi színjátszók előadásaira. ${ }^{107}$ Göttingeni egyetemi éveiről külön tanulmányt lenne érdemes publikálni, mert annak hozadékai megjelentek mind a tudományos munkáiban, mind az esztétika diskurzusában.

104 KAzinczy levele Döbrentei Gábornak, (Széphalom, november 10.), 1818., KazLev, 16. köt. 232

105 „József eme utinaplójából - mely sajnos befejezetlen maradt - látjuk, hogy Bécsből indult és utazása irányát pontosan követhetjük. József is, - mint elődei - Prágán, Drezdán, Lipcsén, rándulást a Harzba, majd pedig Braunschweigen, Brandenburgon át Potsdamba és Berlinbe
utazott, $s$ innen Wittenbergen keresztül tért vissza Göttingába. 1814-ben innen Hannover, utazott, $s$ innen Wittenbergen keresztül tért vissza Göttingába. 1814-ben innen Hannover, Amsterdam, Leiden, Hága, Rotterdam és Harwich érintésével Londonba utazik, a hol 1814 junius 27-ikérỏl keltezve három hónapra tartózkodási engedélyt kap. Angliából távozva, József gróf Calais, Brüsszel, Antwerpen Achen, Köln, Koblenz, Mainz, Frankfurt, Heidelberg Mannheim, Karlsruhe, Stuttgart, Tübingen, Schafhausen, Zürich, Baden, Bern, Solothum és Basel érintésével 1815-ben Párisba ér, a honnan Fontainableau, Chalon, Macon, Lyon, Genf, Lausanne, Turin, Génua, Milano érintésével utazik haza." IvÁNYI 1931, i. m., 25-26.

106, „...az intézet ügye neki szívügye, az intézet maga fogadott gyermeke; az ő élete s az academiáé egy." Lásd Bajza 1847, i. m., 349.

107 „A Theatrumnak a Logeért mér le tettem az 58. Rforintokat.” SzABó András Teleki Lászlóhoz (12. levél) Pest, 1807. aug. 4. MTA Kt M. Irod Lev. 4Rét 137. 109f. Vö. KeréNYI Ferenc, A régi magyar szímpadon, Budapest, Magvető, 1981, 93. 
Teleki József külföldi tanulmányútjáról hazatérve kamarási kinevezést kap, $s$ egyszerre kezdett emelkedni a hivatali ranglétrán, és bekapcsolódni a pesti tudományos és irodalmi életbe (ekkor még apja segítségével). 1816-tól fogva apjával együtt támogatja a Tudományos Gyüjtemény folyóirat megindulását és mủködését, nemcsak előfizetőként és szerzőként, hanem később szerkesztőségi tagként is. A folyóirat a Magyar Tudós Társaság elődintézményeként működött 1818tól 1822-ig. A mögé alapított intézet a személyi egyezéseken túl szerkezetében és célkitűzéseiben is hasonlított a későbbi Magyar Tudós Társaságra. Ennek az elő-akadémiának az alapszabályzatában való kidolgozásban az ifú Teleki József is részt vett, aztán belső tagja, később pedig elnöke lett a csupán pár évig ülésező, félnyilvánosságban múködő társaságnak. ${ }^{108}$ Ezzel párhuzamosan, huszonkilenc esztendős korában nyert a Marczibányi-alapítvány pályázatán. Munkája az előíró helyett a leíró-jellegű nyelvészeti szemléletet részesíti előnyben. E kötet alapján készült el a későbbi Akadémiai nagyszótár. ${ }^{109}$ Teleki József harminc éves korára már több ízben megjelentetett drámabírálatokat, poétikatörténeti-esztétikai dolgozatokat. ${ }^{110}$ Megítélését talán mutatja kissé Kazinczy Ferenccel való levelezése, és hogy Kazinczy mindig pozitívan nyilatkozott róla:

„Én alig várom az időt, a’ mellyben ennek az iffú esztendejü, de nagy készületủ 's tiszta fejủ Urnak ismeretségébe eljuthassak, 's örömmel vallom, hogy én Gróf Teleki Józsefről mondom Literaturánkra nézve ezt: Hic vir hic est, tibi quem promitti saepius audisti! A T. Gy. legközelebbi darabjában is van egy dolgozása, mellyet gyönyörködve olvastam. Legtitkosabb vonásaiban lesem gondolkozását, 's örömmel látom, hogy a’ fej megszabadult bizonyos kelevényektől, mellyek sok jó fejeinket bántják." ${ }^{111}$

Teleki tárgyilagosságára jó példa, hogy amikor Kölcsey Ferenc Berzsenyi-recenziója megjelenését követően Berzsenyi Dániel 1818-ban polemikus antikritikát küld a Tudományos Gyüjtemény szerkesztőségébe, Teleki dönti el, hogy a szöveg

108 Lásd Kollár 2018, i. m., 286-289.

109 TeLEKI József, A magyar nyelvnek tökélletesitése uij szavak és új szóllás-módok által. Jutalom. Feleletek a Magyar Nyelvről a Magyar Nemzeti Múzeum 1815, 1816, 1817. esztendei kérdéseire, Kiadta HoRváth István, Pesten, 1821.

110 Az Eskïvés, szomor (szomorú) Játék öt felvonásban, szerzette G, I., kiadta Döмӧтör Miklós, Udvari hites Jegyző, a’ szerző barátya, Pesten Trattner János Tamás betủivel és költségeivel, 1817., Tudományos Gyüjtemény, 1817/6, 86-94; KemÉnY Simon, Eredeti hazai Dráma két Felvonásban, Barátság és Nagylelküség, Eredeti Dráma, Irta Kisfaludi KIsfaludy Károly, Pesten Trattner János Tamás betúivel, 1820, Tudományos Gyüjtemény, 1822/2, 88-98.

111 Kazinczy levele Szabó Jánosnak, (h. n., jan. 23.), 1820, KazLev, 17. köt., 31. átdolgozásra szorul, $s$ visszaküldendőnek ítéli az antirecenziót. „.... azt a szerzőnek oly kéréssel ítélem visszaküldendőnek, hogy azt újra általnézvén, tulajdon ítélete szerént minden keményebb személysértő kifejezésektől szorgosan megtisztítván vagy jóval megrövidítse, vagy pedig inkább értekező mint antikritikai formába öltöztesse...”. ${ }^{112}$ Berzsenyi ezután dolgozta ki esztétikai értekezését, a Poetai Harmonistikát, amely későbbi Akadémiai székfoglalója volt. ${ }^{113}$ Teleki bírálatainak tárgyilagos hangvétele, objektív szemlélete kritikatörténeti jelentőségű. Ö volt a Tudományos Gyüjtemény hasábjain jelentkező első kritikus, akinek szövege indulatoktól mentesen fogalmazott meg elmarasztaló kritikát, különválasztva a szerző személyétől az alkotás minősítését. Fiatalkori poétikatörténeti tanulmánya egyesek szerint a romantika magyarországi kezdetét jelöli, de a neohumanista esztétika magyarországi megjelenése is részben az ő nevéhez füződik. ${ }^{114}$ Két történeti értekezése jelent meg az Auróra hasábjain 1822-ben és 1823-ban. ${ }^{115}$ E két terjedelmes mű azért jelentős, mert ezek által többé már nem csupán tudománypártoló hazafiként, hanem mint történettudományban is jeleskedő tudós határozhatta meg magát. Ugyanezek az évek az apától való függetlenedés, az apa helyébe lépés évei voltak. Teleki László 1821-ben elhunyt, és József a birtokügyek intézésében is apja özvegye segítségére volt. Az 1820-as évektől több levél is érkezik hozzá erdélyi rokonaitól, akik a különböző birtokdarabok peres ügyeinek sürgető rendezését vagy jogi segítséget kérnek tőle. ${ }^{116}$

Noha több generáción át várták a megfelelő alkalmat a társaságalapításra, az Akadémia alapításába mégis csak akkor kapcsolódott be, amikor az uralkodó

112 OSZK Kézirattár, Fol. Hung. 4. Nem tudható azonban, hogy Berzsenyihez eljutott-e Teleki véleménye, mindazonáltal az Észrevételekben már tudatosan kerüli a személysértést. Berzse-

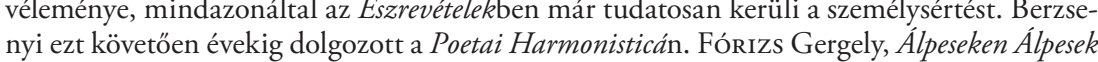
nyi ezt követően évekig dolgozott a Poetai Harmonisticán. Fórizs Gergely, Alpeseken Alpesek emelkednek, A képzéseszménye Berzsenyielméletiszövegeiben, Budapest, Universitas, 2009, 186-

113 A mủ eszmetörténeti kontextusához az is hozzátartozik, hogy Berzsenyire inspiráló hatássa volt Szabó Andrásnak, azaz Teleki József nevelőjének egyetlen publikált esztétikai értekezése. Lásd Fórizs Gergely, A Poétai Harmonistika koncepciójának forrásai és eszmetörténeti kontextusa, ItK, 2006/1-2. (110), 15-47.

114 KolLÁR Zsuzsanna, „Játékszini tekintetben” - Teleki József drámabírálatairól = Drámák határhelyzetben I, szerk. Brutovszky Gabriella, Demeter Júlia, N. Tóth Anikó, Csizmadia Gabriella, Kassa, Nyitrai Konstantin Filozófus Egyetem Közép-európai Tanulmányok Kara, 2014, 315-329; Kollár Zsuzsanna, Egy konfliktus természetrajza, ItK 2018/6 (122), $707-$ 730.

115 Telekr József, Eger várának ostroma 1552-ben, Auróra, hazai Almanach, kiad. Kisfaludy Károly, Pest, Trattner, 1822, 229-252; Elsö Lajos nápolyi hadviselései 1347-1351, Auróra, Karoly, Pest, Trattner, 1822, 229-252; Elso Lajos nápolyi hadviselesei
hazai Almanach, kiad. Kisfaludy Károly, Pest, Trattner, 1823, 41-70.

116 Lásd például Teleki Domokos levele Teleki Józsefhez, MNL OL P 654. 15. d 37. tétel, 14vr-16v-r. Teleki Józsefné $(1832,1836)$, MNL OL P 654 15. d. 37. tétel, 42v-r-43v-r. 
jóváhagyja Széchenyiék felajánlását. ${ }^{17}$ Ezzel az óvatossággal nincs egyedül, az adományozók névsorából is látszik, hogy József nádor adományát követően más aulikus családok is bátrabban álltak mecénásnak. Az Akadémia működését kidolgozó bizottság tagjait 1827. november 30-án nevezte ki a nádor. „Az elnökségre gróf Teleki Józsefet, akkori csanádi főispánt, a Helytartótanácsban közvetlen munkatársát, kérte fel. A kinevezett huszonkét bizottsági tagon kívül meghívást kapott az ülésekre a négy alapító is." ${ }^{118}$

Nem tudni ugyan, hogy ebből az összesen 27 tagú bizottságból hányat ajánlott Teleki, az azonban nyilvánvaló, hogy közülük többen már ismerték őt a Tudományos Gyüjtemény szerkesztőségéből. Széchenyi négy fóliónyi 1827-28-ból származó, Józsefhez írott levele megtalálható a Teleki-levelezésben. A barátságos, közvetlen hangvételből lehet arra következtetni, hogy közöttük ellentét nem volt. 1828. július 2-án Cenkről írja: „A Tudós Társaság gyűlése is tán akkor lesz (...) ha jó előre tudósítni szíveskednél igen nagy köszönettel volnék irántad.” ${ }^{119}$ E levél is erősíti azt feltételezést (és Széchenyi naplóiból is ez derül ki), hogy nem az alapító tartotta kezében a bizottság munkáját, hanem sokkal inkább Teleki, aki tehát Széchenyi és a nádor bizalmát is élvezte. $S$ ilyenformán a bizottság katolikus tagjainak sértődései, melyekről Vaderna Gábor külön fejezetet írt monográfiájában, nem reprezentálják Teleki közmegítélését. Persze ettől még számos ismeretlen körülményre hívja fel a figyelmet Teleki József illetlen viselkedése (zsebre tett kézzel, kézfogást mellőzve üdvözli és búcsúztatja a bizottság a társaság alaprajzát kidolgozó deputáció katolikus tagjait), ${ }^{120}$ azonban a helyzet megértéséhez feltehetően jobban kell ismerni a két felekezet (tudomány)politikai harcait. Teleki elnöki kinevezése pedig már természetesen következett az Akadémia működését kidolgozó deputáció elnöki posztjából. A későbbi években mégis elsősorban politikusként és hivatalnokként működött, tudományos munkára az Akadémiával járó teendők miatt sem volt ideje. Mindemellett mecénásnak sem szűnt meg lenni. Az alapításkor tett pénz- és a könyvtárfelajánlásáról már esett szó. Ezen felül külön jutalomalapítványt is tett drámai művekre 1834-ben. ${ }^{121}$

117 Vö. JolsvaI András, Írók Akadémiája, ItK, 1989/5-6. (93), 605-626.

118 Uo., 622.

119 Gr. SzÉCHENYI István levele Teleki Józsefhez, MNP P 654 25. d 37. tétel, 1015v.

120 VADERNA 2013, i. m., 226- 227.

121 Az 1855-56-os ülés jegyzőkönyve: II. Ez évben némi jutalom-alapítványok kerülvén az akadémia rendelkezése alá, módja lett e téren is a tudományosság és költői munkásságra hatni. Ugyanis két drámai jutalmat ítélt oda gr. Teleki József alapítványából, egy szomorú- s egy vígjátékit. A Magyar Tudományos Akadémia munkálódásaiból s pénztára mibenlétéröl jelentése az Igazgató Tanácsnak, 1847-58, Pesten, Emich Gusztáv nyomtatása, 35. Gróf Teleki József 1834-es külön alapítványáról lásd 41. oldal.
Teleki József és édesapja sokat tettek az Akadémiáért és a tudományok intézményesüléséért, $s$ noha József politikai és tudományos karrierjét tekintve felülmúlta apját, még ő is a 18. századi értelmiségi magatartásformákra korlátozta tudományos működését. Az erdélyi protestánsoknak már a 17-18. században is emelkedett igényük volt a mikroközösségekben megjelenő értelmiségi életformára, ${ }^{122}$ és ez a protestáns fóúri reprezentációba később láthatóan oly mértékben beépült, hogy még a 19. század derekán tevékenykedő akadémiai elnök Teleki művelődéskoncepciójának is egyik alapeleme maradt. 1849 után azonban e helyzet radikálisan megváltozik. Kazinczy Lajos (6. kép) tragikus kivégzése, bátyjának, Teleki Ádámnak rangvesztése és a politikai átrendeződés kiábrándíthatta, ugyanis ettől fogva történészként működött tovább, és megírta A Hunyadiak kora Magyarországon öt kötetét, amelyben a Leopold von Ranke által megteremtett, és a 19. században elterjedt objektivista-historista irányzat módszertanát követte. Szinte már említeni sem kell: a monográfiából bejövő bevételek is az Akadémia pénztárába kerültek. ${ }^{123}$ Mindenképpen érdemes megjegyezni, hogy noha Teleki József 1834-ben a Bajor Tudományos Akadémia tiszteleti tagja, 1838-tól a Magyar Tudós Társaság tiszteleti tagja lett, sohasem választották meg az MTA rendes tagjai közé. ${ }^{124}$

A tudományok és az irodalom intézményesülésének 19. századi mozgalma, ha lehet egyáltalán mozgalomnak nevezni, ${ }^{125}$ azért kedvezett a Telekieknek, mert e téren immár öt generációra visszanyúló tapasztalattal és érdemekkel rendelkeztek. Alaposabb családtörténeti és vagyoni vizsgálat esetén talán a Ráday családban történtekhez hasonló is kimutatható lenne. Ráday Gedeon nem egyszerűen vagyona jelentős részét áldozta fel a könyvgyűjtés oltárán, hanem már komoly egzisztenciális veszélyt jelentett a család számára. ${ }^{126} \mathrm{~A}$ Telekiek vagyona jelentősebb volt annál, semmint hogy a műgyűjtés veszélyeztesse azt, azért mégis feltűnő, hogy már a 17. századtól fogva akadnak szép számmal olyan felmenők, akik kulturális

122 Sipos Gábor, Tanulmányok az erdélyi református egyház 16-18. századi történetéhez, EME, Kolozsvár, 2012.

$123 \mathrm{Uo}$.

124 Ebben annak is szerepe lehetett, hogy 1849 és 1859 között az Akadémiát felfüggesztették, és ez alatt az idő alatt tagfelvétel sem volt.

125 Lásd Thimár Attila intézmény-fogalmát: THIMÁr Attila, „A TÁRSASÁG ÁLLAPOTJA” Egy irodalmi intézménytörténeti adatbázis megtervezésének tanulságai, ItK, 2001/12 (105), Egy irodal
$90-106$.

126 „Olyan versenytársakkal kellett felvenni a küzdelmet, mint a császári bibliotéka, vagy herceg Liechtenstein, vagy akár a magyar Festeticsek és Telekiek, akiknek mind sokkalta nagyobb anyagi erő állt rendelkezésükre könyvgyűjtő szenvedélyük kielégitésére, mint Rádaynak. Segesváry Viktor, A Ráday Könyvtár 18. századi története, Hága, Mikes International, 2005,64 . 
és a tudományos praxisaikra más családokhoz képest aránytalanul nagy összegeket és időt áldoztak. Könnyedén találunk példát az akadémiai elnök levelezésében is arra, hogy külföldön megforduló ismerőseikkel, ügyvédekkel, nevelőkkel, peregrinusokkal, tudósokkal könyveket hozatnak maguknak kisebb-nagyobb öszszegekért. ${ }^{127}$ Mindezzel párhuzamosan pedig a 1840-es évek elején Teleki (IV.) József is kölcsönök felvétele iránt is érdeklődött, s kapott is ajánlatokat kedvező és kedvezőtlenebb kamattal egyaránt. ${ }^{128}$ Ebből látszik, hogy míg a szakirodalom sokszor egyszerűen csak arisztokrataként hivatkozik a Telekiekre, addig a Pálffy, Eszterházy, Batthyányi, Erdődy, Nádasdy, Zichy, Csáky és a többi családhoz képest a Telekiek társadalmi helyzete jóval összetettebben megítélhető, hiszen vagyonukkal arányosan a politikai súlyuk is kisebb lehetett.

A Telekieknél a birtok-, a vagyon- és a tekintélyszerzés éppúgy intergenerációs hatóerővel bírt, mint ahogy kultúrapártoló tevékenységük is tudatos családi stratégia eredményeként értékelhető. Az erdélyi kapcsolati hálók magyarországi kiterjesztése olyan politikai és gazdasági érdekszövetséget hozott létre, amely a polgári réteg későbbi erősödése alatt is hozzájárult az erdélyi főrangúak hatalmi pozícióinak és tekintélyének fenntartásához. ${ }^{129}$ Mindezek fényében jogosan vetődhet fel, hogy a Telekiek a megfelelő szellemi környezet megteremtésével valójában a kulturális cselekvés politikai hasznosíthatóságára törekedtek. E tekintetben a tudományok intézményesítésének, így az Akadémia alapításának szimbolikus politikai dimenziója is volt társadalmi funkciója mellett, hiszen illeszkedett a magyar politika rendi struktúráról a parlamentárisra való átrendeződésének folyamatába.

127 Lásd például TeLEKI (III.) László Baló Sámuellel való levelezését, a több száz, olykor több ezer forint értékủ könyvvásárlásokról. MTAK Kézirattár Magyar Irodalom negyedrét 137.

128 Magyar Nemzeti Levéltár Országos Levéltára, P 654, 37. tétel 69-74f.

129 Lásd az Értelmiség címủ fejezetet itt: MaKкaI László, Mócsy András, Szász Zoltán, Erdély története három kötetben II., föszerk. KöPEczy Béla, Budapest, Akadémiai, 1986.

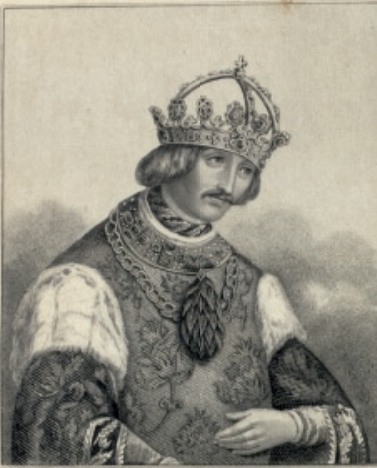

\section{ALESBT WAGYASS RUBALY.}

\section{HUNYADIAK KORA}

MAGYARORSZÁGON.

ints

GRÓF TELEKI JÓZSEF.

ELsỏ Кötet.

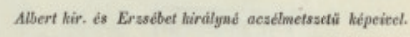

PESTEN,

BMCH ES EISENFELS KOOXYYYYOMDASA

1. kép Teleki József: Hunyadiak kora Magyarországon. Első kötet (Pest, 1852)

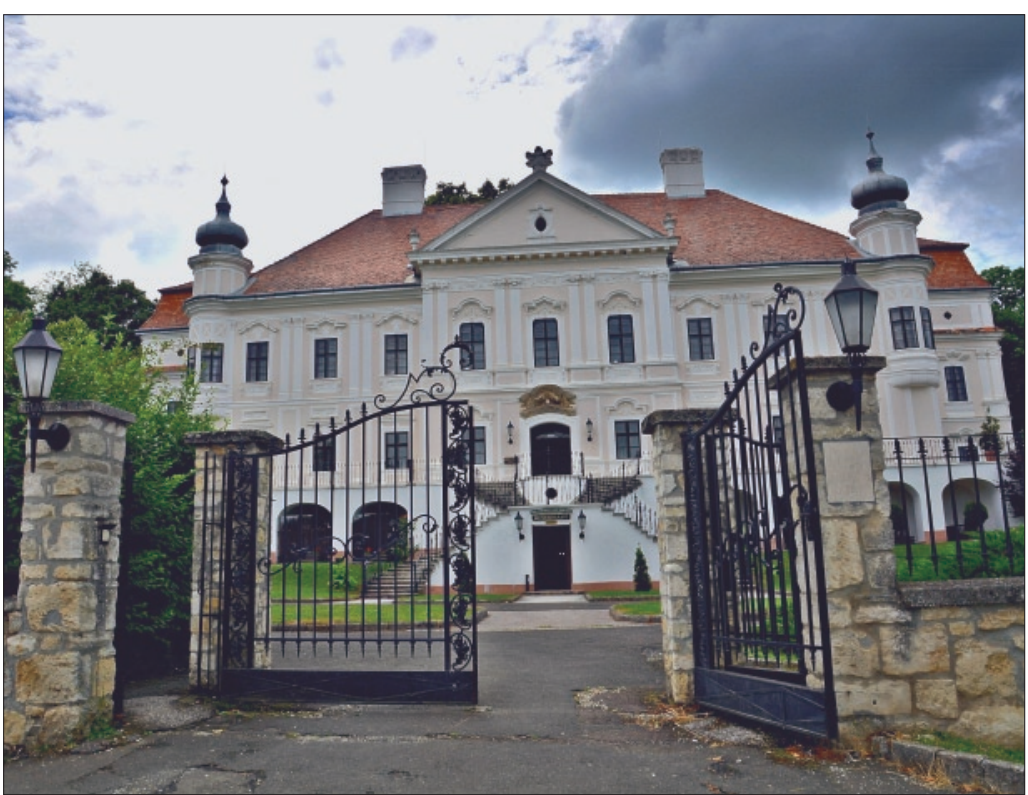

2. kép A sziráki Teleki-kastély ma 


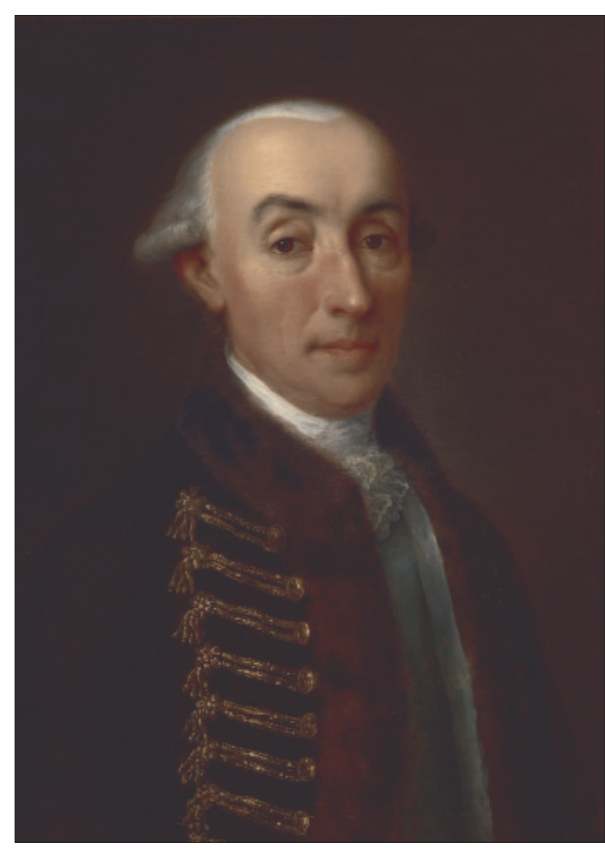

3. kép Teleki József (1738-1796) portréja. Ismeretlen festö, Teleki Téka, Marosvásárhely

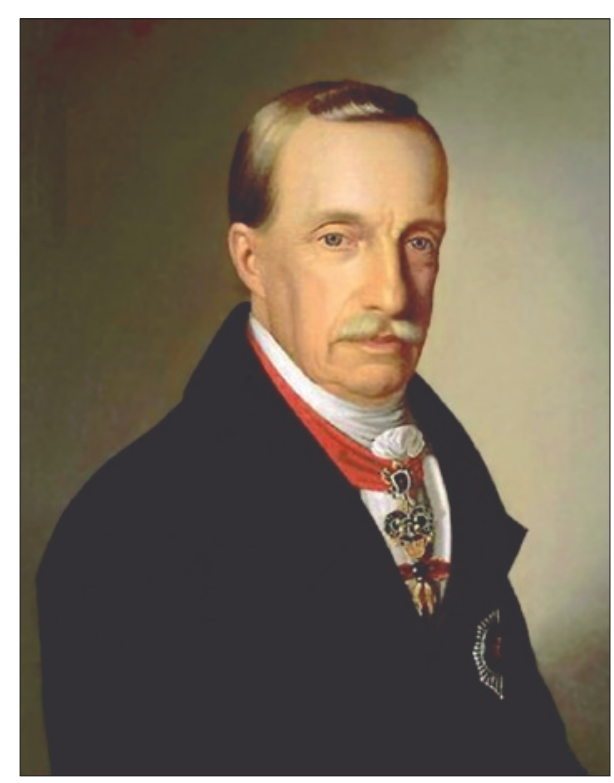

5. kép Habsburg-Lotharingiai József Antal János főherceg (1776-1847), József nádor, Magyarország nádora. Barabás Miklós festménye, 1846

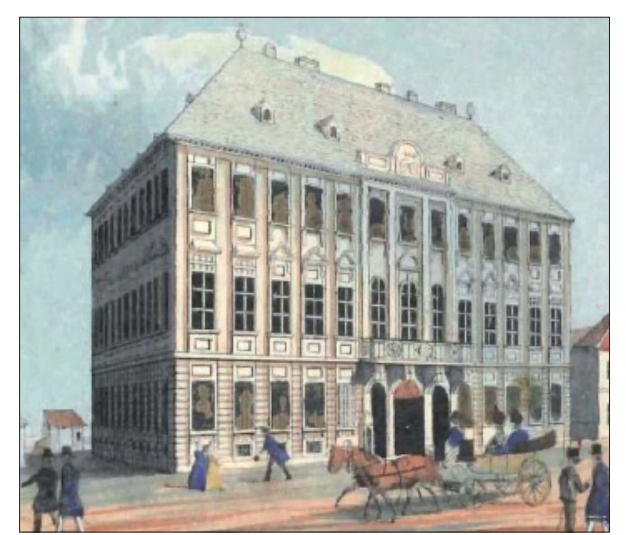

4. kép A Teleki-palota 1837-ben a budai Szentgyörgy téren, Vasquez litográfíája

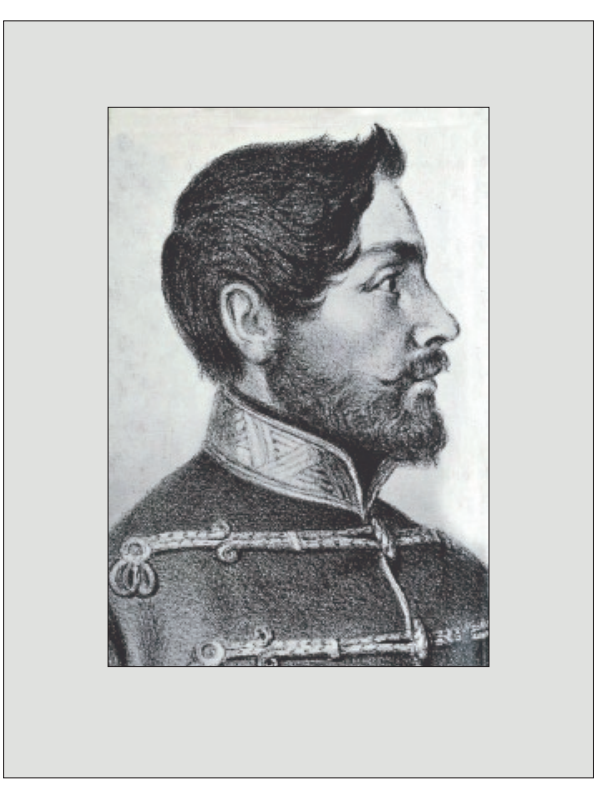

6. kép Kazinczy Lajos (1820-1849), Kazinczy Ferenc legfiatalabb gyermeke, Teleki József pártfogoltja, a „tizenötödik aradi vértanú

\section{SZABÓ ÁDÁM}

A Teleki család és a könyvek

Amíg Széchenyi István akadémiaalapító felszólalása az 1825-ös diétán figyelmet és meglepetést keltett, addig Teleki József gróf következő évi bejelentése, amellyel családi könyvtárukat felajánlotta a frissen alakult intézmény javára, ha nagyvonalúságában nem is maradt el a „legnagyobb magyar” gesztusa mögött, az őt ismerô hallgatókat valószínúleg nem érte annyira váratlanul. Nemcsak azért számíthattak valami effélére a részéről, mert mind ő, mind az édesapja, Teleki László aktívan részt vettek a magyar tudományosság szervezésében és művelésében, hanem azért is, mert a könyvek szeretete, ismerete és gyüjtése generációkra visszamenőleg a família számos tagját jellemezte, úgyszólván családi hagyománynak számított. Ha tehát akadt olyan gyüjtemény az országban, amely méltó volt rá, hogy a nemzet első számú tudományos könyvtárának az alapját képezze, akkor a százötven éves tradíción alapuló, három generáción át fejlesztett pesti bibliotéka kétségkívül ebbe a kategóriába tartozott. A jelen tanulmány ennek a rendkívüli kulturális háttérnek az érzékeltetése végett nagy vonalakban bemutatja a Telekiek könyvgyűjtő tevékenységét: a saját kollekcióval rendelkező családtagok könyvtárának jellegére, sorsára vonatkozó adatokat, az első dokumentált eseményektől az akadémiai könyvtáralapítás, illetve az alapító Teleki József koráig.

A bibliofil hajlam valóban egyidősnek mondható a család felemelkedésével: már a grófi címet szerző és a família jövőjét megalapozó erdélyi kancellárnak, Teleki Mihálynak (1634-1690) az apjáról, Teleki János (?-1648) kővári kapitányról feljegyezték, hogy voltak könyvei. ${ }^{2}$ Maga a kancellár pedig, aki politikai tevékenysége mellett rengeteg időt és anyagi forrást áldozott a hazai kultúra fejlesztésére, komolyan foglalkozott könyvgyűjtéssel. Magához vette apja könyv-

DOI-azonosító: 10.36820/MTAKIK.KOZL.2019.TELEKI.2

Magának az Akadémiai Könyvtárnak, illetve az alapító állományának a történetét e kötet Teleki-gyüjtemény az Akadémián címú tanulmánya mutatja be.

2 F. Csanak Dóra, Két korszak határán: Teleki József, a hagyományörzö és a felviláoosult gondotkodó, Budapest, Akadémiai Kiadó, 1983, 188. 